University of Rhode Island

DigitalCommons@URI

Open Access Master's Theses

1998

\title{
REFINING LOCAL SUBDIVISION REGULATIONS TO PROMOTE GOOD DEVELOPMENT IN NANTUCKET, MASSACHUSETTS
}

Eric Savetsky

University of Rhode Island

Follow this and additional works at: https://digitalcommons.uri.edu/theses

\section{Recommended Citation}

Savetsky, Eric, "REFINING LOCAL SUBDIVISION REGULATIONS TO PROMOTE GOOD DEVELOPMENT IN NANTUCKET, MASSACHUSETTS" (1998). Open Access Master's Theses. Paper 588.

https://digitalcommons.uri.edu/theses/588

This Thesis is brought to you for free and open access by DigitalCommons@URI. It has been accepted for inclusion in Open Access Master's Theses by an authorized administrator of DigitalCommons@URI. For more information, please contact digitalcommons-group@uri.edu. 


\title{
REFINING LOCAL SUBDIVISION REGULATIONS \\ TO PROMOTE GOOD DEVELOPMENT
}

IN

NANTUCKET, MASSACHUSETTS

by

ERIC SAVETSKY

\begin{abstract}
A RESEARCH PROJECT SUBMITTED IN
PARTIAL FULFILLMENT OF THE

REQUIREMENTS FOR THE DEGREE OF

MASTER OF COMMUNITY PLANNING
\end{abstract}

UNIVERSITY OF RHODE ISLAND

1998 


\section{MASTER OF COMMUNITY PLANNING}

\section{RESEARCH PROJECT}

OF

ERIC SAVETSKY

Approved:

Major Professor

Acknowledged:

Director

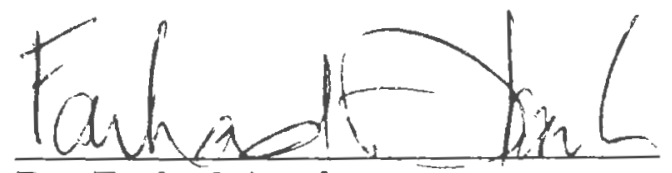

Dr. Farhad Atash

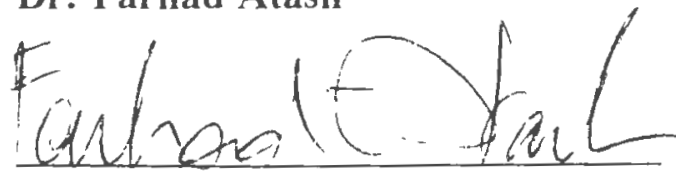

Dr. Farhad Atash 


\begin{abstract}
This study provides recommendations that should be considered by Nantucket and its Planning Board to promote better subdivision development on the Island. New subdivision development will have a strong alfeet on the physical appearance of the Island. The Planning Board responsible for review and permitting of new subdivisions should strive to promote development which blends in with the historical style of development. The existing subdivision regulations do very little to promote good development and were probably borrowed from another community in Massachusetts and adopted.
\end{abstract}




\section{ACKNOWLEDGEMENT}

I would like to take this opportunity to thank the following people who helped see this study through to completion; Dr. Farhad Atash for his time, commitment, and guidance on this project; John Pagini for his advice, encouragement, and ideas; my partner Ann Fitzgerald and my parents for their continued encouragement and support: and the many towns of the Commonwealth of Massachusets that patiently provided me with vital information for this project. 


\section{TABLE OF CONTENTS}

\section{Chapter One: Introduction}

1.1 Topic of Research \& Its Significance . . . . . . . . . . . . . 1

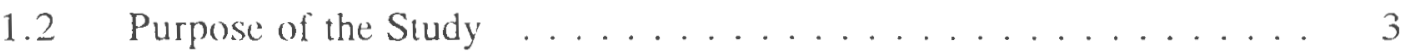

1.3 Methodology/ Approach of the Study .............. 4

1.4 Scope of the Study . . . . . . . . . . . . . . . . 5

\section{Chapter Two: Overview of Nantucket}

2.1 Introduction to Nantucket . . . . . . . . . . . 7

2.2 Population Characteristics ................. 8

2.3 Land Use . . . . . . . . . . . . . . . . . . .

2.4 Historic Land Development . . . . . . . . . . . . . 10

2.5 Potential for Future Development . . . . . . . . . . . . 12

Chapter Three: Nantucket's Subdivision Regulations and Development on Nantucket

3.1 Review of the Existing Subdivision Regulations ............ 14

3.2 Analysis of Existing "In-Town" Subdivision Development . . . . . . 19

3.3 Analysis of Existing "Out-of-Town" Subdivision Development . . . 24 


\section{Chapter Four: Review of Subdivision Regulations of Other Communities}

4.1 Design Guidelines . . . . . . . . . . . . . . . . . . . . . . 29

4.2 Street Layout . . . . . . . . . . . . . . . . . . 30

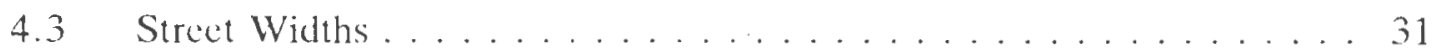

\section{Chapter Five: Literature Review}

5.1 Homeowner Preferences . . . . . . . . . . . . . . . . . . 34

5.2 New Urbanism/Neotraditional Planning . . . . . . . . . . . 35

Chapter Six: Recommendations for Revising Nantucket's Subdivision Regulations

6.1 Purpose Statement . . . . . . . . . . . . . . . . . 38

6.2 Design Guidelines . . . . . . . . . . . . . . . . 38

6.3 In-Town Development Category ....................... 39

6.4 Out-of-Town Development Category ................. 41

6.5 Roadway Layout . . . . . . . . . . . . . . . . . . 41

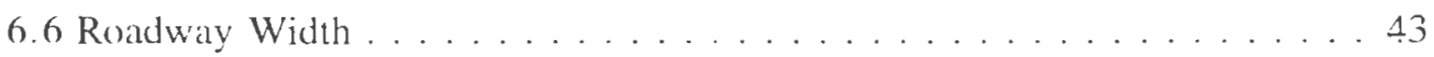

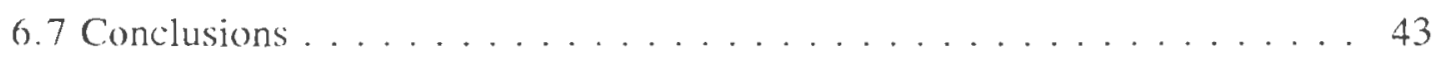

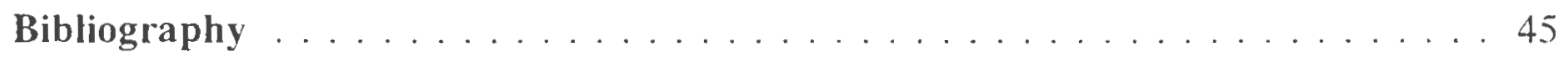




\section{LIST OF TABLES}

Table 1: Historical Population Growth ............. 8

Table 2: Population Growth in the 1990's . . . . . . . . . . . 8

Table 3: Nantucket Land Use Pattern . . . . . . . . . . . . . . . 9

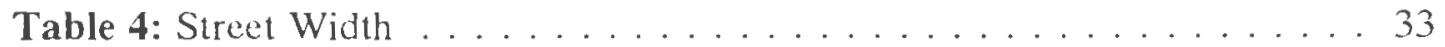

Table 5: Summary of Subdivision Features . . . . . . . . . . . . 34 


\section{LIST OF FIGURES}

Figure 1: Map of Southeastern Massachusetts ............ 7

Figure 2: Open Space Map . . . . . . . . . . . . . . . . . 10

Figure 3: Downtown Street Map ................. 11

Figure 4: Downtown Street . . . . . . . . . . . . . . . . . 11

Figure 5: Subdivision of an Existing House Lot ........... 13

Figure 6: Cul De Sac Diagram ....................... 18

Figure $7:$ Woodbury Lane Subdivision ................ 20

Figure 8: Nashaquisett Subdivision . . . . . . . . . . . . . . 21

Figure 9: Naushop Subdivision . . . . . . . . . . . . . . . 22

Figure 10: Hedge Row Subdivision . . . . . . . . . . . . . . . 23

Figure 11: Cul De Sac at Hedge Row .................. 24

Figure 12: Curvelinear Street Pattern ................ 25

Figure 13: Tom Nevers Subdivision ................. 25

Figure 14: Marion Acres Subdivision ............... 26

Figure 15: Chip-Sealed Road ... . . . . . . . . . . . 27

Figure 16: Subdivision Road with Narrow Shoulders . . . . . . . . 28

Figure 17: Turning " $\mathrm{L}$ " and Turning "T" Layouts . . . . . . . . . . 42 


\section{Chapter One \\ Introduction}

\subsection{Topic of Research and Its Significance}

The topic of this study is subdivision development on Nantucket, Massachusetts and how to make new development blend in with the historic pattern of development on the island. Growth in the form of land development is a major force of change in any community. The creation of new building lots through subdivision is the first step in the growth process. It sets the character of an area to be developed by laying out the road network and associated infrastructure such as sidewalks, landscaping, and street furniture. The layout of new subdivisions will strongly influence the look and character of the areas surrounding them.

Typical suburban style subdivisions look completely out of character on Nantucket. In addition, the typical suburban subdivision lacks character in general and is nothing more that a cookie cutter approach to divide the land into developable lots which meet the minimum lot size of a given zoning district.

Many local subdivision regulations, including Nantucket's, do little to promote "good development". Typical cul de sac road designs with extensive asphalt typify most develonments. In addition, most subdivision regulations do little to promote both pedestrian and bicycle connections to other neighborhoods and the downtown. In fact, there are many aspects of local subdivision regulations which influence the way a subdivision eventually effects the surrounding area. The local subdivision regulations are a developer's guide and rule book for preparing a development plan for any given piece of land. If the subdivision regulations do nothing to promote 
"good development" a developer can easily get off on the wrong foot when designing a subdivision, and making changes after costly initial design work becomes more difficult.

Some subdivision regulations go as far as creating incentives for cluster style subdivisions, including Nantucket's regulations, which can be a step in the right direction. But, many communities subdivision regulations could do more to promote "good development". Nantucket's subdivision regulations are a perfect example of a generic set of regulations that do not relate specifically to the Island's unique character. New subdivisions will have a significant impact on the character of their surrounding areas and therefore should be carefully designed and reviewed under the subdivision regulations. If the local regulations are inadequate the developer has little to go by, the reviewing agency may not have the authority to require an appropriate design, and the subdivision may end up looking out of character. Therefore, it is extremely important that the local subdivision regulations reflect what the community is looking for in new development.

It is surprising that Nantucket's subdivision regulations do not do more to promote a style of development that is in keeping with the Island's historic character. The entire island is designated as a historic district, which adds to the importance of having subdivision regulations that promote "good development". The historic character varies from area to area on the Island, from the downtown with its whaling history, to outlying rural areas, and to the seattered small "villages" which have developed over time. The different areas on the Island have somewhat difterent character, but all should interrelate to form a cohesive community.

In November 1990 the Town of Nantucket adopted the Goals \& Objectives for Balanced Growth by vote at the annual Town Meeting. This document was designed to be the Town's overall, long-range comprehensive planning policy and guide for the management of future 
growth. Objective C-8.2, in the category of Growth Management reads as follows:

C-8.2 Develop land use and zoning measures which are more reflective of the traditions and character of historic village centers and outlying rural areas.

The subdivision regulations are one of the main land use regulations in Nantucket and can directly affect the character of development on the istand. This study will develop better subdivision regulations to more positively influence the character of development. The fact that developing better land use regulations (ie. subdivision regulations) was a goal adopted by the entire community makes this study significant. Since 1990, the existing subdivision regulations have not been amended with regard to this community goal.

\subsection{Purpose of the Study}

The purpose of this study is to develop creative amendments for the Nantucket Subdivision Rules \& Regulations which can be incorporated in order to promote better development. As stated earlier, the subdivision regulations are a developer's guide and rule book for planning a potential development. It is at this critical time, during the planning stages, that good subdivision regulations must be available to guide and promote development that fits in the surrounding environment and has appropriate character.

This project will specifically address following aspects of subdivision regulations:

1. Roadway design - a major contributing factor to the character of a subdivision.

2. Pedestrian and bicycle connections - vital to connecting neighborhoods.

3. Preservation of existing landscape - in many subdivisions the natural landscape is lost due to unnecessary clearing and grading. 
In addition to these major topics, many other areas for needed improvement will be identilied and solutions proposed. Unfortunately, Massachusetts enabling legislation severely restricts the scope of control that a local planning board may have over proposed development. Therefore, this study will not address topics outside a planning board's jurisdiction such as architectural guidelines or siting guidelines.

\subsection{Methodology/Approach of the Study}

First, the island of Nantucket will be introduced. The island's unique character will be described, along with the vital statisties which make Nantucket what it is today. This is an important step because it sets the framework developing amendments designed to enhance the good characteristics of the island.

The next task will be to assess existing development on Nantucket to identify models of good development which the amended regulations will strive to promote. In addition, Nantucket's stock of developable land will be assessed so that the proposed amendments can be specifically targeted towards the remaining developable land on the island.

Once the local conditions have been assessed and described, a review of subdivision regulations from other communities in Massachusetts will be conducted to identify existing ideas which may be used to improve Nantucket's regulations. This will be followed by a literature search to identify other good ideas which will promote better development on Nantucket.

Using an extensive bibliography of innovative ideas in this field, as well as experience gained from actual use of the existing regulations, including input from the Nantucket Planning Board responsible for implementing the regulations, and input from active developers on 
Nantucket, the relevant sections of the existing regulations will be rewritten, transforming a generic set of subdivision regulations into an innovative regulation which encourages better development.

\subsection{Scope of the Study}

The scope of this study will be the limited to revising Nantucket's subdivision regulations. Atthough research will include ideas from the current literature throughout the country, these ideas if applied will have to be in conformance with the Massachusetts enabling legislation known as Massachusetts General Laws, Chapter 41, The Subdivision Control Law. In Massachusetts, subdivision legislation and zoning legislation are two completely separate subjects with no legal overlap. Changes to the local zoning bylaw require a two/thirds vote of all citizens attending the local town meeting, whereas, changes to the subdivision regulations only require the Planning Board to hold a public hearing and vote upon the proposed changes. Therefore, this study will focus on proposed changes to the subdivision regulations, without getting into the underlying zoning which controls the density of any subdivision proposal.

Within the subdivision regulations, the study will focus on topics which significantly affect the aesthetics and character of a development. The study will not get into every aspect of the subdivision regulation which needs improvement, as this would be too broad a scope. Instead it will focus on roadway design and the infrastructure which goes along with it, such as landscaping, sidewalks, street lighting, etc. The major questions to be addressed throughout this research project are as follows: 
1. What types of subdivisions (ic. size, zoning district, character) will comprise the majority of future applications?

2. What areas of the Nantucket "Rules \& Regulations Governing the Subdivision of Land" could be improved upon with regard to promoting better subdivisions?

3. What constitutes good and not so good subdivision in Nantucket, Massachusetts?

4. What are the latest develupments in innovative subdivision design?

5. What are the experts recommending in the way of subdivision design?

6. What regulations and incentives can be developed to promote better subdivisions? 


\section{Chapter 2}

\section{Overview of Nantucket}

\subsection{Introduction to Nantucket}

Nantucket, Massachusetts is a small island, approximately 49 square miles or 31,700 acres in area, located 25 miles south of Cape Cod. The island measures roughly 14 miles long by three miles wide.

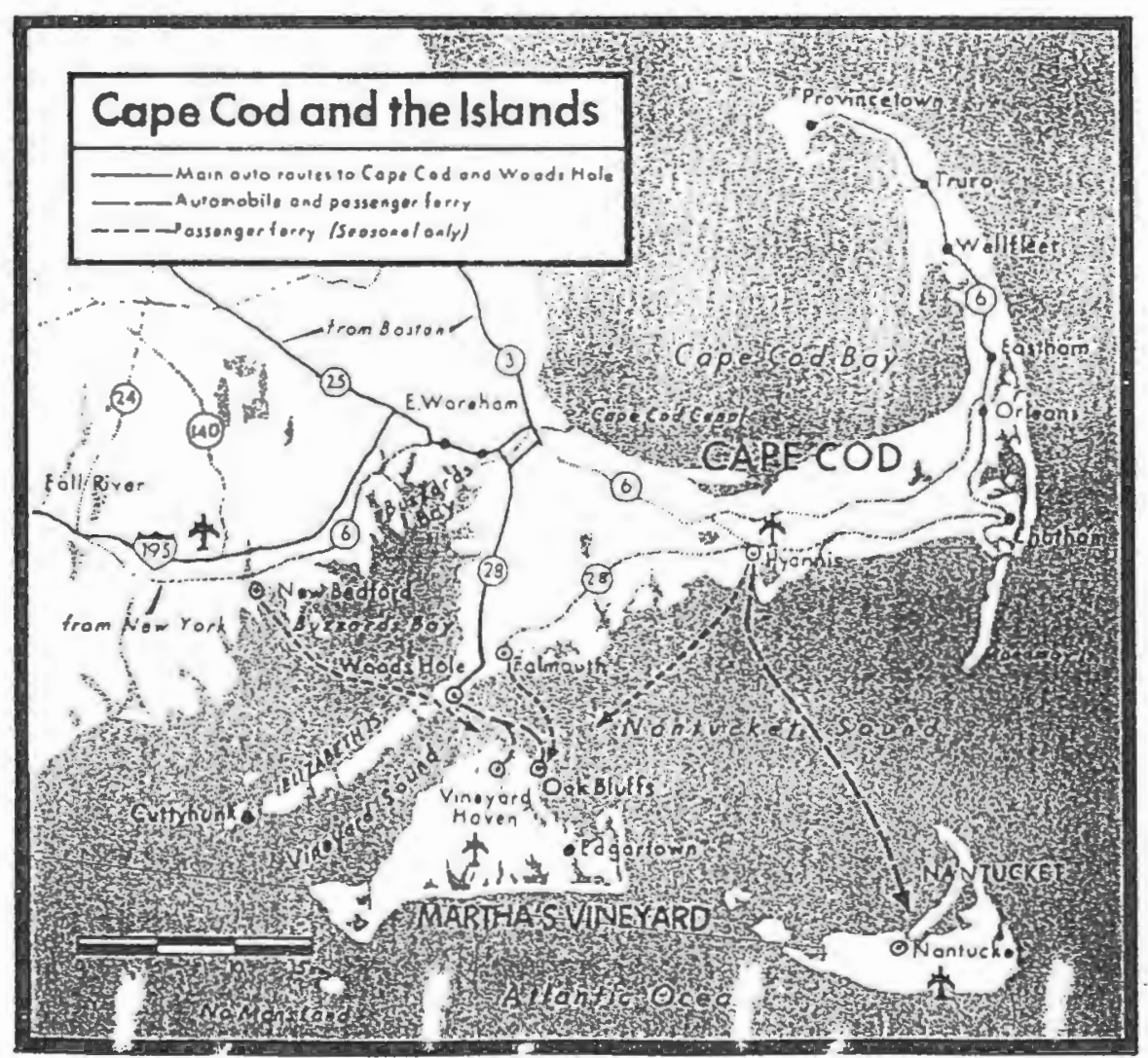

\section{FIGURE 1: Map of Southeast Massachusetts}

This small island is known around the world for its whaling history and is now a major international summer tourist destination. According to a historical map produced in 1869 by Reverand Doctor Ferdinand C. Ewer, the Town of Nantucket incorporated in 1672 and the population grew steadily to a peak of 9,712 in 1840 . After that point the whaling industry started 
to decline and by 1865 the population was estimated at only 4,830 .

\subsection{Population Characteristics}

The U.S. Bureau of the Census indicates that the 1995 year-round population was 7,153 and it has been estimated that on a peak summer day the island may have as many as 45,000) people in total.

TABLE 1: Historical Population Growth

\begin{tabular}{|c|c|c|c|c|c|c|}
\hline & 1940 & 1950 & 1960 & 1970 & 1980 & 1990 \\
\hline \hline Population & 3,401 & 3,484 & 3.559 & 3,774 & 5,087 & 6,012 \\
\hline$\%$ Change & & $2.4 \%$ & $2.2 \%$ & $6.0 \%$ & $34.8 \%$ & $18.2 \%$ \\
\hline
\end{tabular}

Source: Nantucket Community Profile, 1997.

TABLE 2: Population Growth in the 1990's

\begin{tabular}{|c|c|c|c|c|c|c|}
\hline & 1990 & 1991 & 1992 & 1993 & 1994 & 1995 \\
\hline \hline Population & 6,036 & 6,128 & 6.223 & 6,437 & 6,842 & 7,153 \\
\hline \% Change & $0.4 \%$ & $1.5 \%$ & $1.6 \%$ & $3.4 \%$ & $6.3 \%$ & $4.5 \%$ \\
\hline
\end{tabular}

Source: Nantucket Community Profile, 1997.

As Table 1 shows, the population remained fairly stable until the 1970's when it started to grow more rapidly. Table 2 shows that population growth during the 1990 's until 1995 is still at higher rates than prior to the 1970's. This growth in population has been aceompanied by an increase in the number of houses on Nantucket. Of the approximately 8,000 existing homes on Nantucket, roughly $80 \%$ are summer homes. 
Currently, the Island is seeing an extremely strong surge in the real estate market. This surge is being felt throughout most of the country due to the strong economy. Many people are attracted to Nantucket for its seclusion, relative lack of crime, clean environment, charm and character, and sense of community. Nantucket is truly a special place but new development threatens to turn it into just another ordinary place.

Approximately 12,106 acres, almost $40 \%$, of the land area on Nantucket has been permanently preserved as open space.

Table 3: Nantucket Land Use Pattern

\begin{tabular}{|c|c|c|c|}
\hline & 1987 & 1991 & 1997 \\
\hline \hline Developed Land & $13 \%$ & $23 \%$ & $30 \%$ \\
\hline Undeveloped Land & $53 \%$ & $40 \%$ & $30 \%$ \\
\hline Conservation Land & $34 \%$ & $37 \%$ & $40 \%$ \\
\hline \hline TOTAL & $100 \%$ & $100 \%$ & $100 \%$ \\
\hline
\end{tabular}

Source: Nantucket Long Range Transportation Plan, 1993.

Nantucket was the first place to form a land bank which assesses a $2 \%$ tax on all real estate transactions. First time homebuyers are not assessed for the first $\$ 100,000$ of the purchase price. This tax is used to purchase land for open space and recreation. In addition, in the 1970's through the efforts of the Nantucket Conservation Foundation, many substantial gifts of land were given by large property owners. Considering the current value of land on Nantucket, the Island is very fortunate to have amassed this high percentage of land area for permanent open space (see Figure 2). 


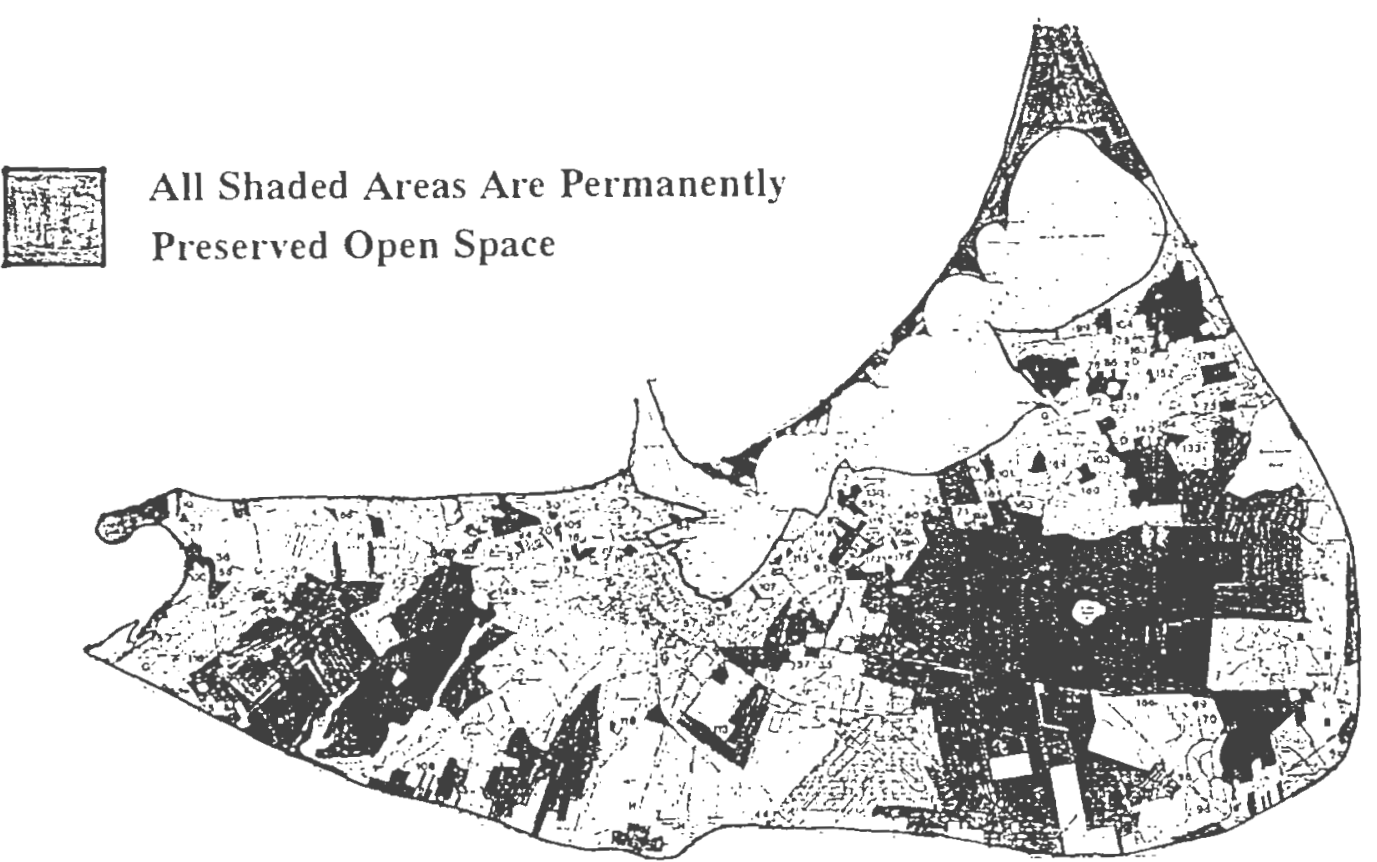

Figure 2: Open Space Map

Given Nantucket's long history, much of the island's existing development has taken place on building lots which pre-date the local and state subdivision regulations. Due to the strong real estate market on Nantucket (ranked second fastest growing town in Massachusetts) most of the pre-existing lots have been developed and there is a strong demand for additional building lots. This coupled with the high value of real estate drives an extremely active land development market.

\subsection{Historic Land Development}

The Island has a large historic downtown centrally located on the north side adjacent to the harbor. The downtown was largely developed prior to zoning and subdivision regulations. The streets are laid out in a rectilinear pattern and are very narrow as se't in ligures 3 and 4 on the following page. 


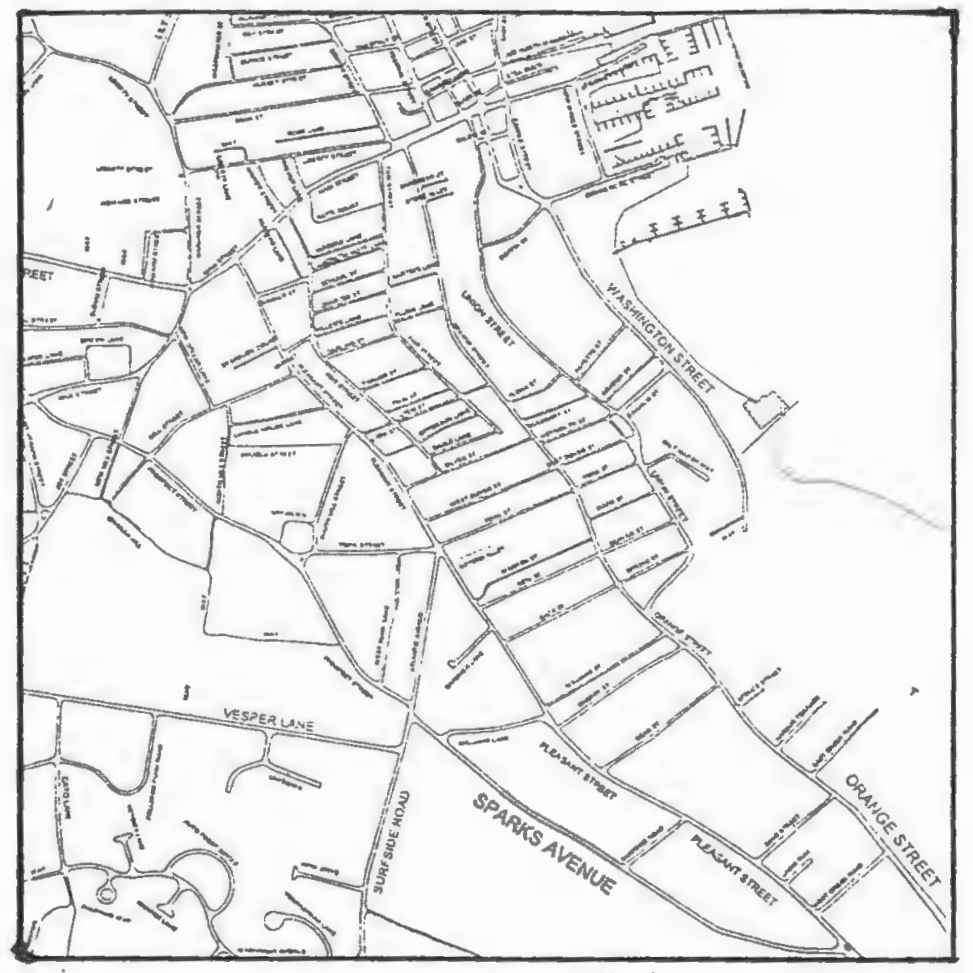

Figure 3: Downtown Street Map

The houses are set very close to the streets with only a sidewalk separating them from the street and they usually cover most of the very small lots they are located on.

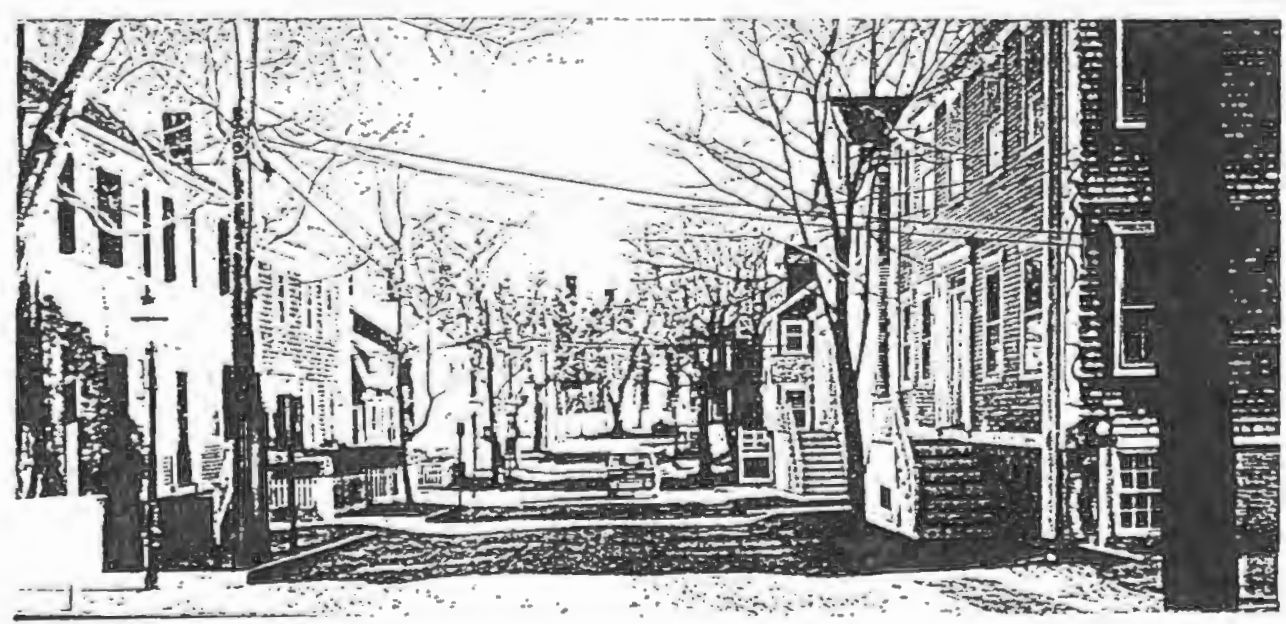

Figure 4: Downtown Street

As you move out of the downtown core the street pattern and house layout starts vary with 
angular street layout and larger lots. These immediately outlying areas were largely developed during the 1960's and 1970's as the year-round population expanded slowly.

Aside from a few small village style settlement areas outside of town which evolved long ago, the rest of the island is characterized by rural style development. This has been a function of the original zoning which was adopted in 1972 setting the minimum lot sizes for the entire island.

\subsection{Potential for Future Development}

It is important to assess the potential for future development on Nantucket so that the revisions to the subdivision regulations can focus on the actual types of subdivisions which will make up the majority of future applications. Table 3, on a previous page, shows that the amount of land going into development is increasing at a higher rate than the amount of land going into conservation. This is due to the diminishing amount of available open land and its corresponding increase in cost. Although $30 \%$ of the landmass is still undeveloped, a significant portion of this land may not be developable for reasons such as wethands, coastal flood and erosion problems,

and other constraints. Therefore, the table is somewhat misleading because an actual survey of land available for development reveals relatively few large parcels with signilicant development potential.

As more and more people are attracted to Nantucket the existing stock of buildable lots will begin to shrink causing an increased demand for new buildable lots. The increased demand for new lots coupled with the lack of supply of existing lots will cause the priee of buildable lots to increase to the point where redivision of existing lots which exceed twice the minimum lot sizes 
for their respective zoning district will become very attractive. This type of infill or redevelopment is already on the increase. The Building Commissioner reports a growing number of applications for demolition or relocation of existing structures. Much of this growth is generated by owners who have subdivided a lot with existing structures upon it which now need to be relocated to accommodate the new lot line or lines.

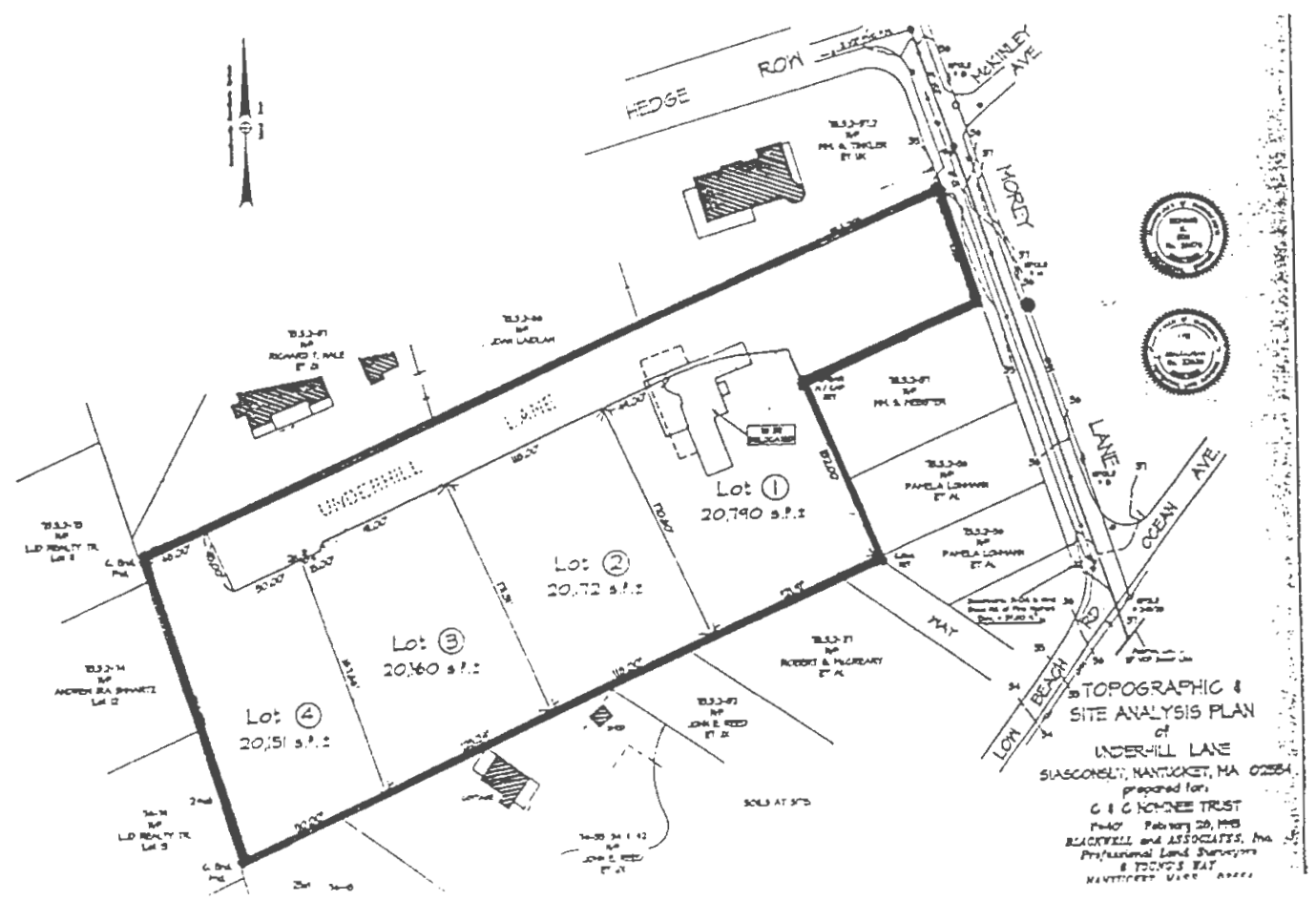

Figure 5: Subdivision of an Existing House Lot

Figure 5 illustrates a situation where an older house on an oversized lot was moved to make room for a new road and the creation of 4 buildable lots on the existing lot which had previously been a single house lot. The other type of subdivision which will account for many of the future applications will be two to ten lot rural subdivisions in the outlying areas. There will not be very many subdivisions of over ten lots because there are very few larger tract of vacant land left. Therefore, efforts to create revisions to Nantucket's subdivision regulations will focus on these "infill" and small rural types of developments. 


\section{Chapter 3 \\ Nantucket's Subdivision Regulations and Development on Nantucket}

\subsection{Review of the Existing Subdivision Regulations}

The existing subdivision regulations do an inadequate job of promoting development which is in keeping with the historic character of Nantucket. As this review shows, there are very few areas which deal with considerations with regard to aesthetics.

The first thing one will lind in most subdivisions regulations is a purpose section. Nantucket's purpose section reads as follows:

\subsection{Purpose}

These regulations have been adopted for the purpose of protecting the safery, convenience and welfare of the inhabitants of Nantucket by regulating the laying out and construction of ways in subdivisions providing access to the several lots therein, but which have not become public ways, and ensuring sanitary conditions in subdivisions and, in proper cuses, parks and open space.

In achieving these purposes, the powers of the Board shall be exercised:

1.03a With due regard for the provision of adequate access to all of the lots in a subdivision by ways that will be safe and convenient for travel;

1.03h For lessening congestion in such ways and in the adjucent public ways;

$1.03 \mathrm{c}$ For reducing danger to life and limb in the operation of motor vehicles;

1.03d For securing safety in the case of fire, fleod, panic and other emergency;

1. OBe For ensuring compliance with the Zoning Bylaw;

I.03f For securing adecuate provision of water, sewerage, drainage, underground utility senice, fire, police and other municipal equipment, street lighting and other requirements, where necessary, in a subdivision: 
$1.03 g$ For coordinating the ways in a subdivision with each other and with the public ways in the Town and with the ways in neighboring subdivisions;

1.03h To advance the community master plan known as the Town's Goals and Objectives for Bulanced (rrowth, as amended from time to time by the Town Meeting, such plan to be construed as conforming to Section 81-D of Massachusetts (ieneral Laws Chapter 41.

As you can see, there is no mention of aestheties with regard to subdivision design other than the subsection 1.03 h reference to the master plan. It is very inportant for a developer to be guided early on in the design process so that a project gets off on the right foot. In addition, having designs goals stated explicitly in the regulations gives the planning board a basis for critically reviewing the aesthetic elements of a project's design. Without mention of design goals, a planning board would have little defense in a court of law should they deny a project for aesthetic reasons, and have their decision appealed by the developer. Therefore suggestions for amendments to the purpose section will be made later in Chapter 6.

The next section of the regulations that touches on design eonsiderations is Section III entitled "Subdivision Layout Design Standards". This section sounds like it would be where some of the design considerations belong. The problem is there is hardly anything in the section to really promote good development. The subsections are titled as follows:

\section{SECTION III SUBDIVISION LAYOUT DESIKN STANDARDS}

$\begin{array}{ll}3.01 & \text { ZONING } \\ \text { 3.02 } & \text { PUBLIC OPEN SPACES } \\ \text { 3.03 } & \text { PROTECTION OF WETLANDS } \\ \text { 3.01 } & \text { FIOOD PRONE AREAS } \\ \text { 3.05 } & \text { PROTECTION OF NATURAL FEATURES } \\ \text { 3.1)6 } & \text { ONE DIUELIING PER LOT }\end{array}$




\subsection{FURTHER SUBDIVISION}

3.08 HIAZARDS

3.09 REVERSE LOT FRONTAGE

3.10 STREET SYSTEM

The only subsection which does anything to promote good design is 3.05, Protection of Natural Features, which reads as follows:

Due regard shall be shown for all natural features, such as large trees, water courses, scenic points, historic locations and similar community assets which, if preserved, will add attractiveness and value to the neighborhood.

This is a very important section to have, and a step in the right direction, but there needs to be much more said in the regulations about how subdivisions should look.

In the Street System subsection (3.10) there is a brief mention of street layouts "respecting the natural contours of the land as far as possible." Again, this is a step in the right direction but much more needs to be included to promote good development.

The only other section of the regulations that deals with design is Section IV entitled "Design Standards and Required Improvements." The majority of this section deals with road construction standards. As I have pointed out from the start, roadway design is probably the single most important feature of a subdivision affecting the character of a development. It is the most visible aspect of a development.

Nantucket's currently has two road construction categories, "Minor" and "Secondary", and a discretionary subcategory called the "Rural Road Alternative". The "Rural Road Alternative" is one of the only elements of the existing regulations that promotes creative development to suit the area in which a project is proposed. The "Rural Road Alternative" is designed to give a developer an alternative to traditional asphalt paving in rural areas if the number of proposed lots 
is low enough. The only problem with the gravel surface is that is cannot withstand too much traffic without breaking down. Experience on Nantucket indicates that this type of road surface would work for development under approximately eight lots. With any more traffic the road surfice would deteriorate too quickly and would required repairs too frequently to be a viable option. The gravel type road surface that this section proposes is much more in keeping with the country setting of these subdivisions and is one of the few elements of the existing regulations that promotes sensitive development..

Another positive feature of Nantucket's existing regulation is the requirement to place all utilities including electric, telephone, and cable TV underground. Telephone poles and the associated wires running through the countryside significantly detract from the visual experience of a rural area.

Most of the other design sections actually promote development which is entirely out of scale with Nantucket, especially given the predicted small size of future subdivision. Road width requirements call for a minimum 20 foot width. This is fairly wide considering that some of the most heavily travelled roads on Nantucket are around 20) to 22 feet wide. Historically, Nantucket's road have always been very narrow. As long as a subdivision is small enough, narrower roads look much less obtrusive on the landscape and actually serve to keep traffic speeds down.

Subsection 4.04, Dead-End Streets, calls for a turn-around at the end of the street with a minimum outside radius of 50 feet and a landscaped island in the center (see Figure 6). 


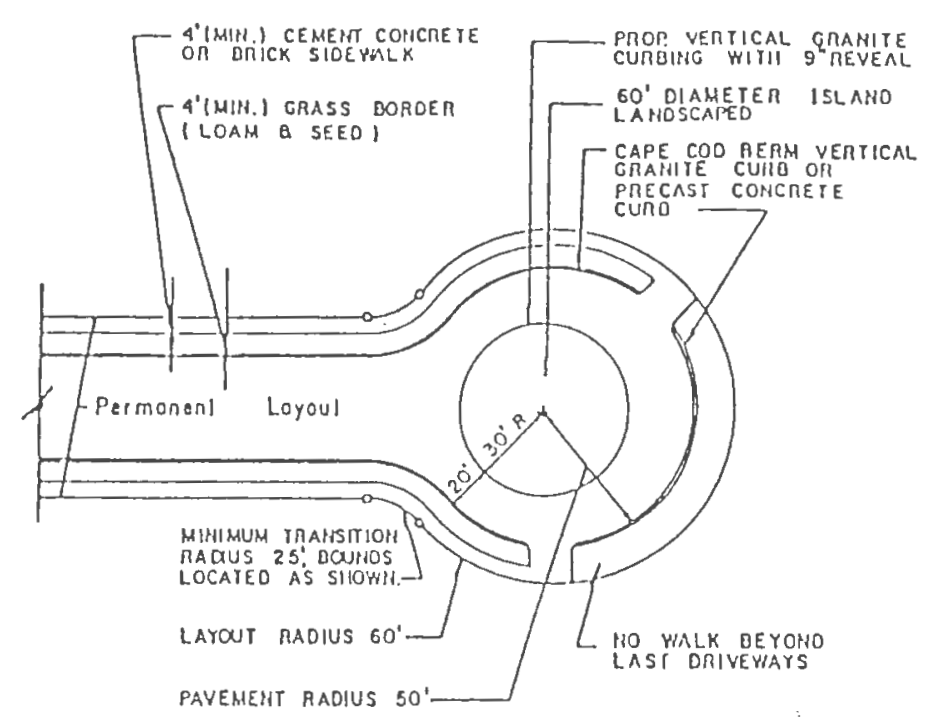

Figure 6: Cul-De-Sac Diagram

Source: Naniucket Subdivision Regulations

This "lollipop" looking turnaround looks very out of place an Nantucket. It is not a traditional road layout style. The regulations do mention alternative designs briefly, but in appropriate situations, the regulations should promote smaller turnarounds such as "turning tees" or "hammerhead' types. These will be discussed in the recommendations section later.

Also in the "Design Standard and Required Improvements" is the requirement for four-foot wide shoulders on either side of a constructed road. This requirement causes the cleared area of a new road to be significantly wider. In many instances it causes unnecessary stripping of topsoil and removal of natural vegetation. Therefore, the road has an even wider appearance for many years until natural vegetation grows back in. Recommendations for improvements to this subsection will be made.

As this review reveals, there are very few areas of the existing regulations that promote good development. In addition, there are many areas of the regulations that actually require improvements which are entircly not in keeping with Nantucket's historic character. These 
requirements are to common to most all generic standard regulations. They were primarily developed by civil engineers with a locus on safety. In most instances these generic standards are meant for much larger subdivisions where major roads will be constructed to caring many more cars at higher speed. While safety is an extremely important consideration, road design and construction can be catered to the size of a proposed development and still be safe, resulting in much better looking subdivision development.

\subsection{Analysis of Existing"In-Town" Subdivision Development}

Nantucket's downtown was developed long ago and has a very distinct look. This is mainly due to the fact that there was no zoning at that time to mandate minimum lot size and minimum front yard setback. Another major factor was the narrow, sometimes cobblestone, streets which were not designed to accommodate automobiles. The street pattern has the traditional character of straight layouts and right angle intersections known as a rectilinear pattern.

The Woodbury Lane Subdivision, built in 1987 , is an excellent example of a new development which was designed in keeping with the nearby historic downtown (see Figure 7). 


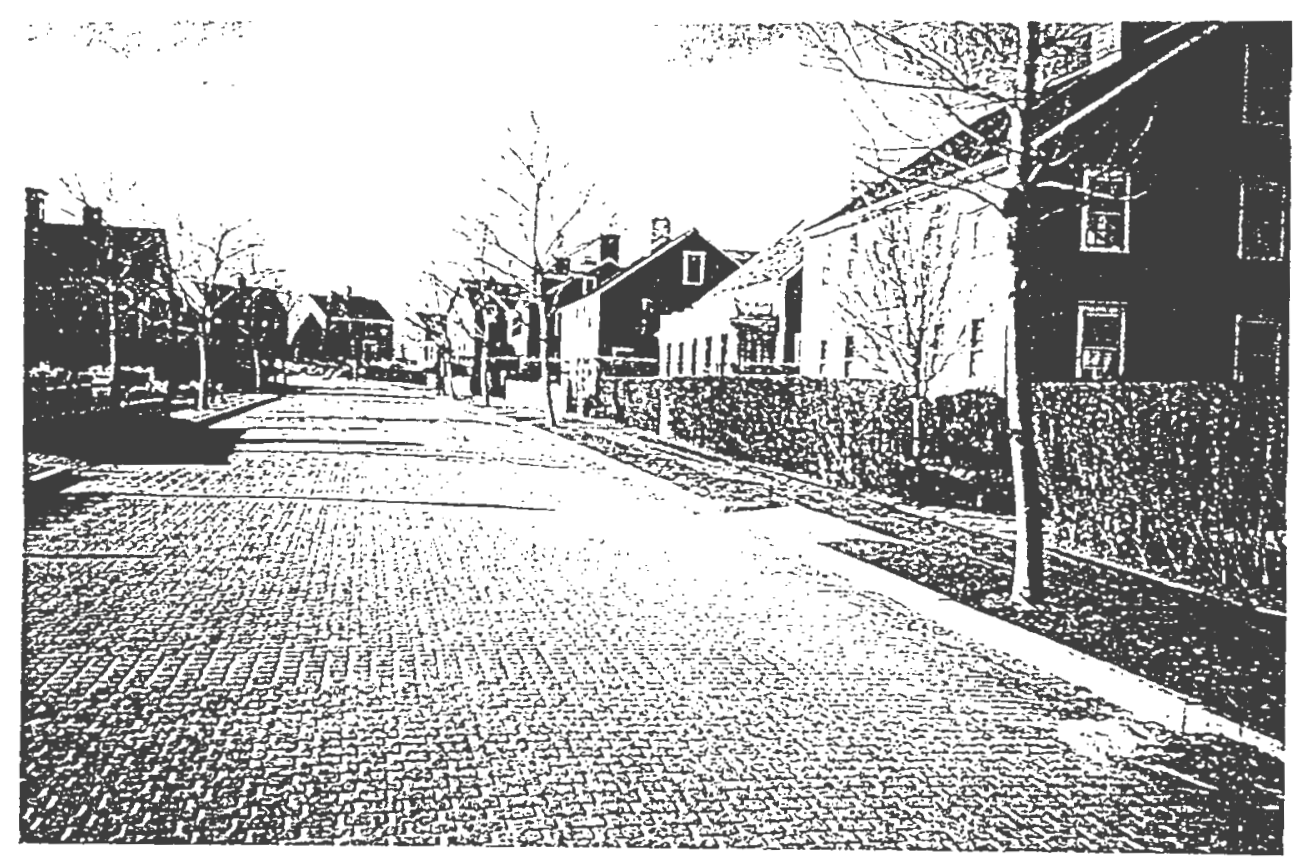

Figure 7: Woodbury Lane Subdivision

It is characterized by fairly small $(20,0)(0)$ square foot) lots, rectilinar roads, grey brick pavers instead of asphalt, brick sidewalks, strectamps, and mandatory archilcetural review for all proposed homes. The houses are all sited along the street line setting the facade and are complimented by picket fences and substantial street tree plantings. Linfortunately this is not the typical new development located near the downtown. It is a very upscale development with vacant half-acre lots now prieed at $\$ 450,000$ each. The reason for the high price is the charm of the development and its close proximity to the downtown. 
Another good example of a newer in-town development is the Nashaquisett Subdivision.

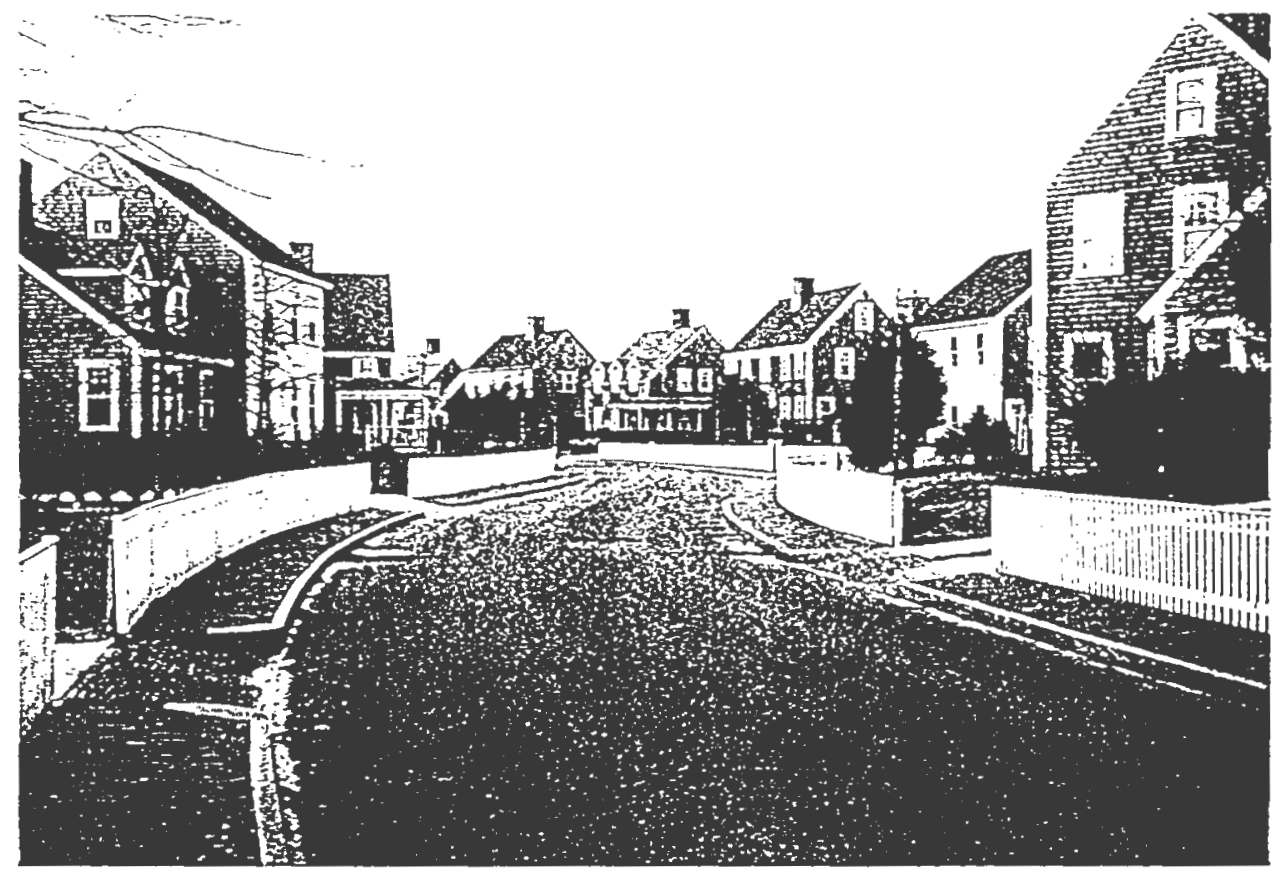

Figure 8: Nashaquisett Subdivision

It is characterized by small lots (7,000 square foot), picket fences, brick sidewalks, extensive landscaping. and mandatory architectual review (see Figure 8). Homes in this subdivision sell for approximately $\$ 350,000$. Although this is an attractive subdivision, due to the picket fences, high density, and landscaping, there is dangerously poor sight distances. In athition, the sidewalks are too narrow and have no grass strip separation from the roadway, which adds to the poor sight distances. One of the major reasons for the suceess of this development is strong architectural review of all proposed homes and required landscaping. 
An example of a less expensive in-town development with attractive characteristics is the Naushop subdivision.

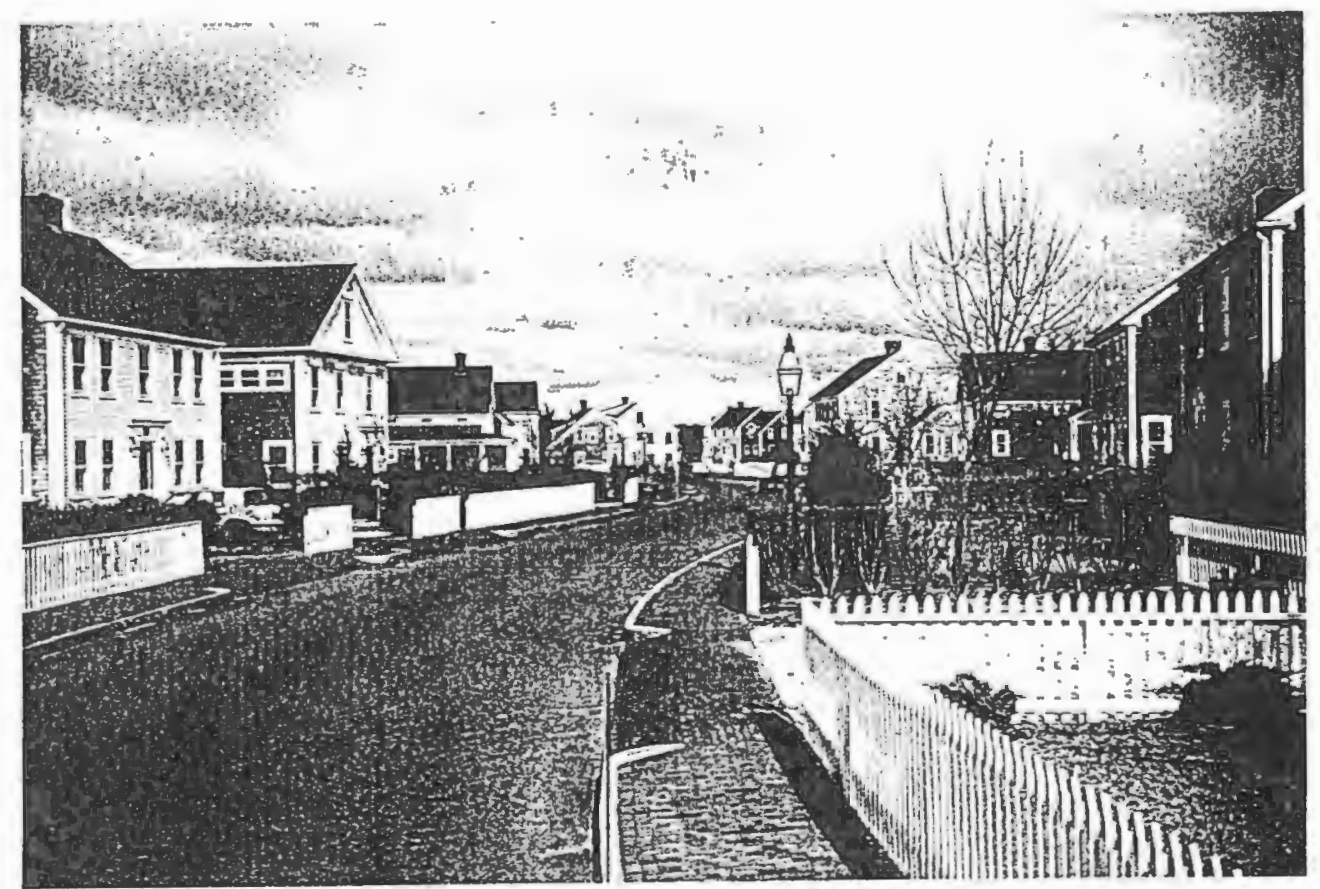

Figure 9: Naushop Subdivision

Homes in this development sell for approximately $\$ 300,000$. This development has brick sidewalks, gas lamp style street lights, picket fencing, the houses are sited along the street line.

As indicated in the review of the previous subdivisions, there are several common elements which contribute to a successiul project. These elements are; brick sidewalks, street trees, rectilinear road patterns (with the exception of the Nashaquisett Development), street lamps, picket fences, and architectural review of homes. These elements, with the exception of architectural review, are borrowed from the older historic downtown development pattern and are why these newer developments have been successtul. They are successful because they blend in with surrounding preexisting development nicely, and because they have been desireable to buyers. 
In contrast to the previous examples of development which blend in well with existing development, an example of an in-town style subdivision which does rou have all of the elements necessiry w blend in with surrounding developnent is the Hedge Row Subdivision.

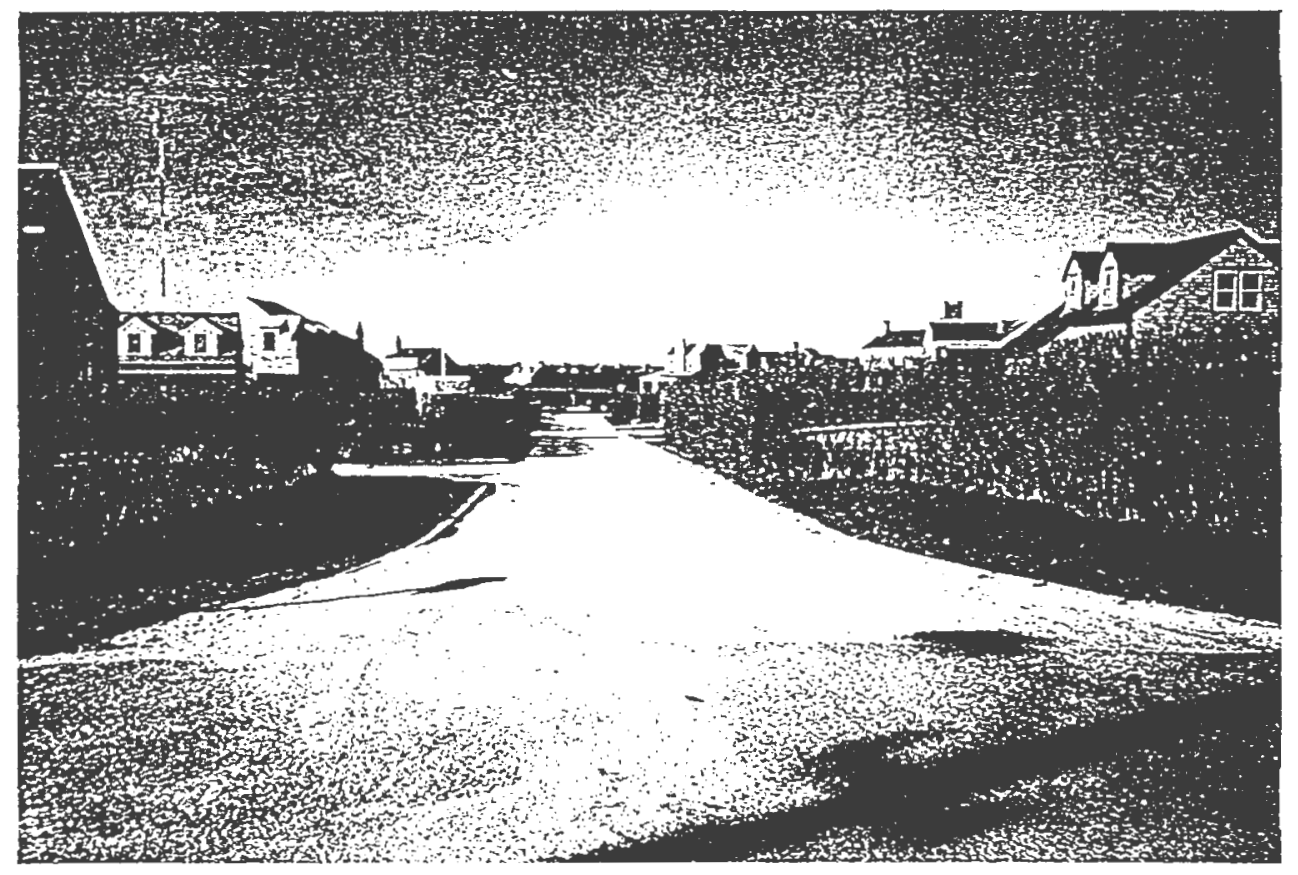

Figure 10: Hedge Row Subdivision

Although the street was surfaced with clam shells in keeping with many older streets in the area, the development still lacks character. There is a lack of a strect facade because the houses are set too far back from the road (sce Figure 10). 


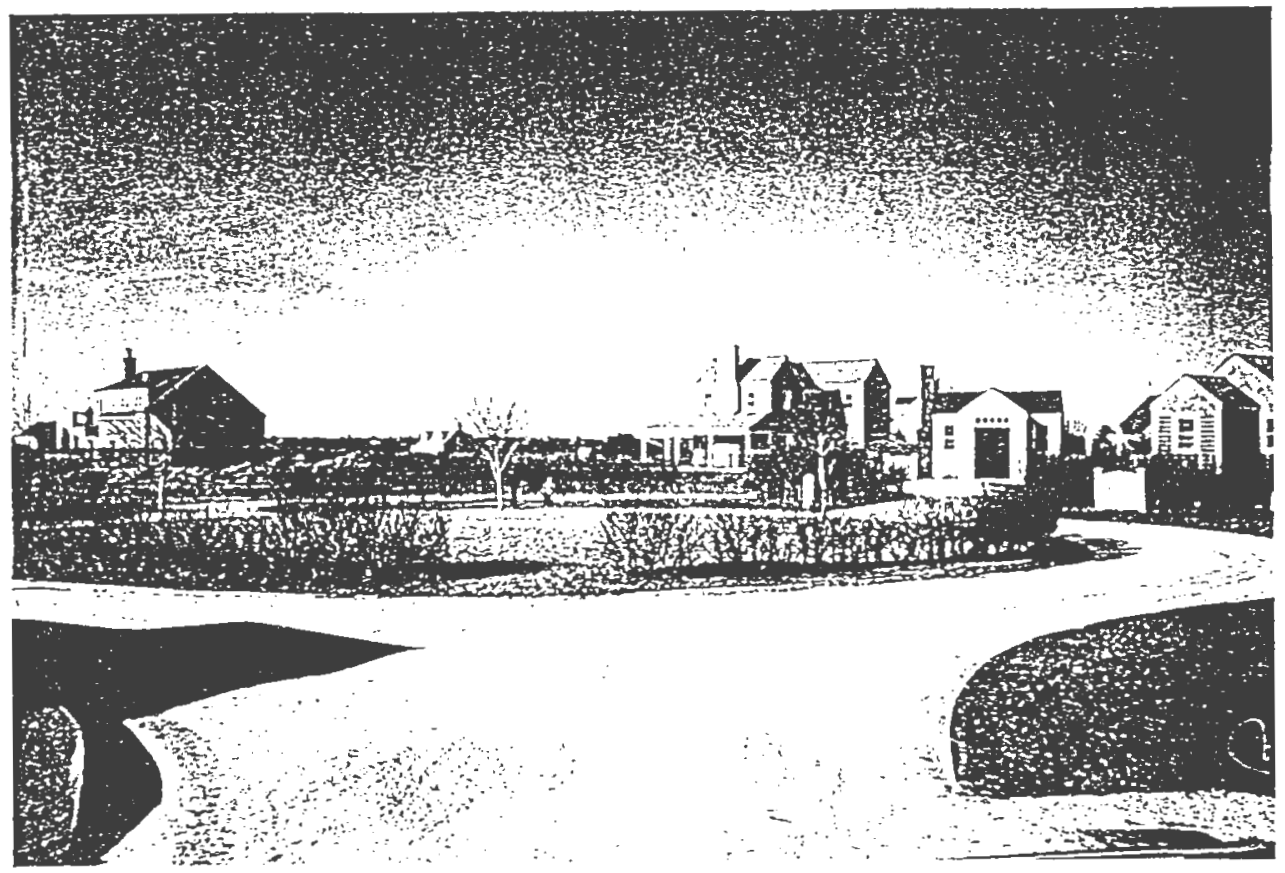

Figure 11: Cul De Sac at Hedge Row Subdivision

The cul-de-sic turn-around at the end of the street looks totally out of place. There was no such thing as a cul-de-site when most of the surrounding area was developed. In addition, the lack of street trees and sidewalks leave the development lacking in historical character (see Figure 11).

\subsection{Analysis of Existing "Out-of-Town" Subdivision Development}

Out-of-town development is generally rural in character. A curvilinear street pattern is more appropriate for these types of developments. The curvilinear pattern allows the roads to follow the natural contours of the land. 


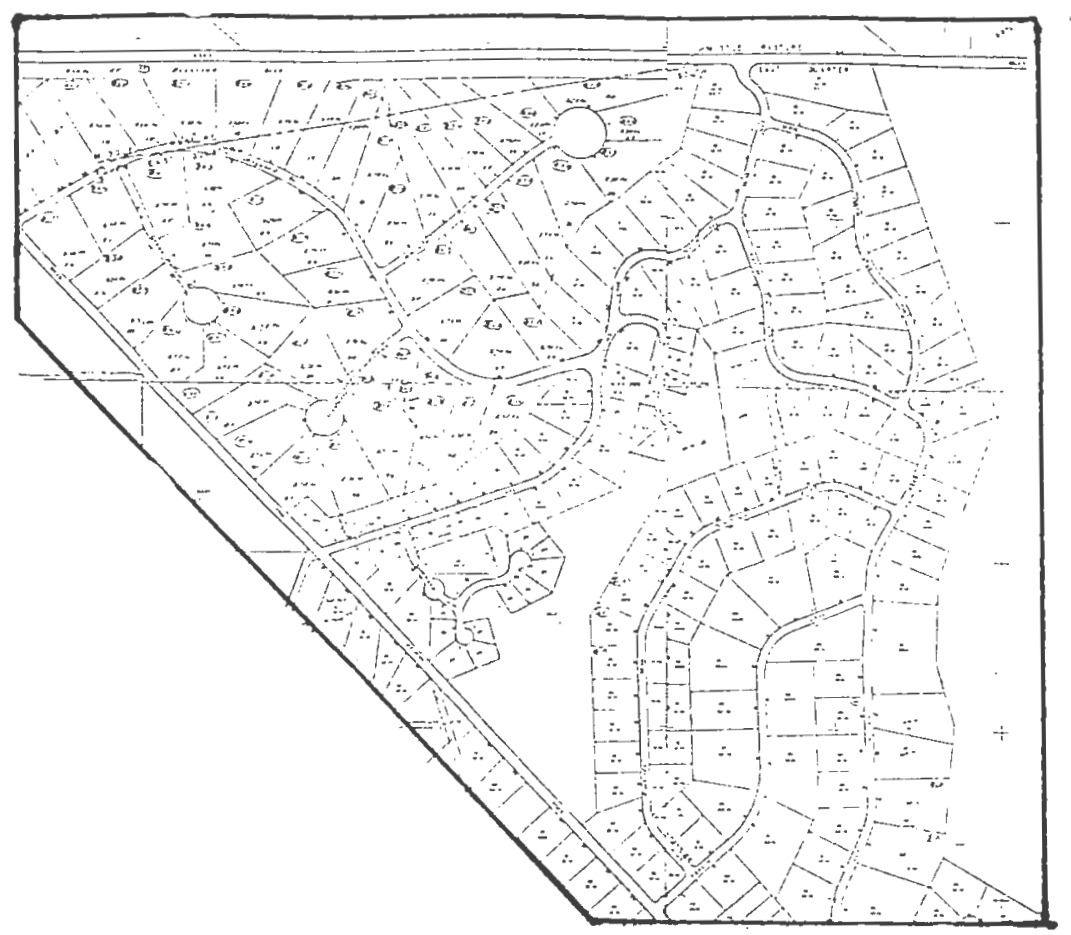

Figure 12: Curvelinear Street Pattern

The gently curving layout of the streets in the above subdivision more easily blend the road in with the surrounding landscape. Straight runs of asphalt would look very unnatural and detract from the soft appearance that makes this a good rural development.

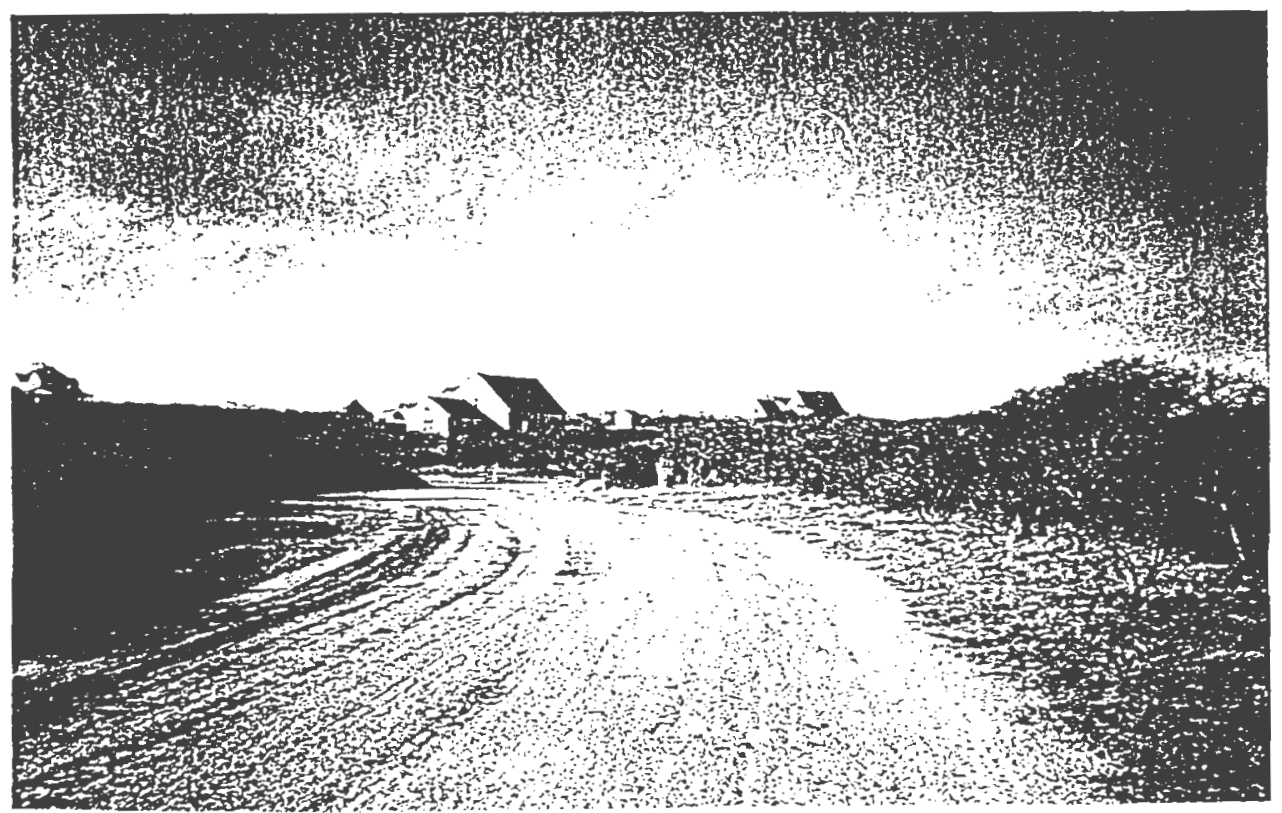

Figure 13: Tom Nevers Subdivision 
Figure 13 shows one of the roads from the subdivision depicted in Figure 12. Notice how the road blends with the natural landscape. In contrast, the photograph below (Figure 14) clearly shows how a straight run of road dominates the landscape.

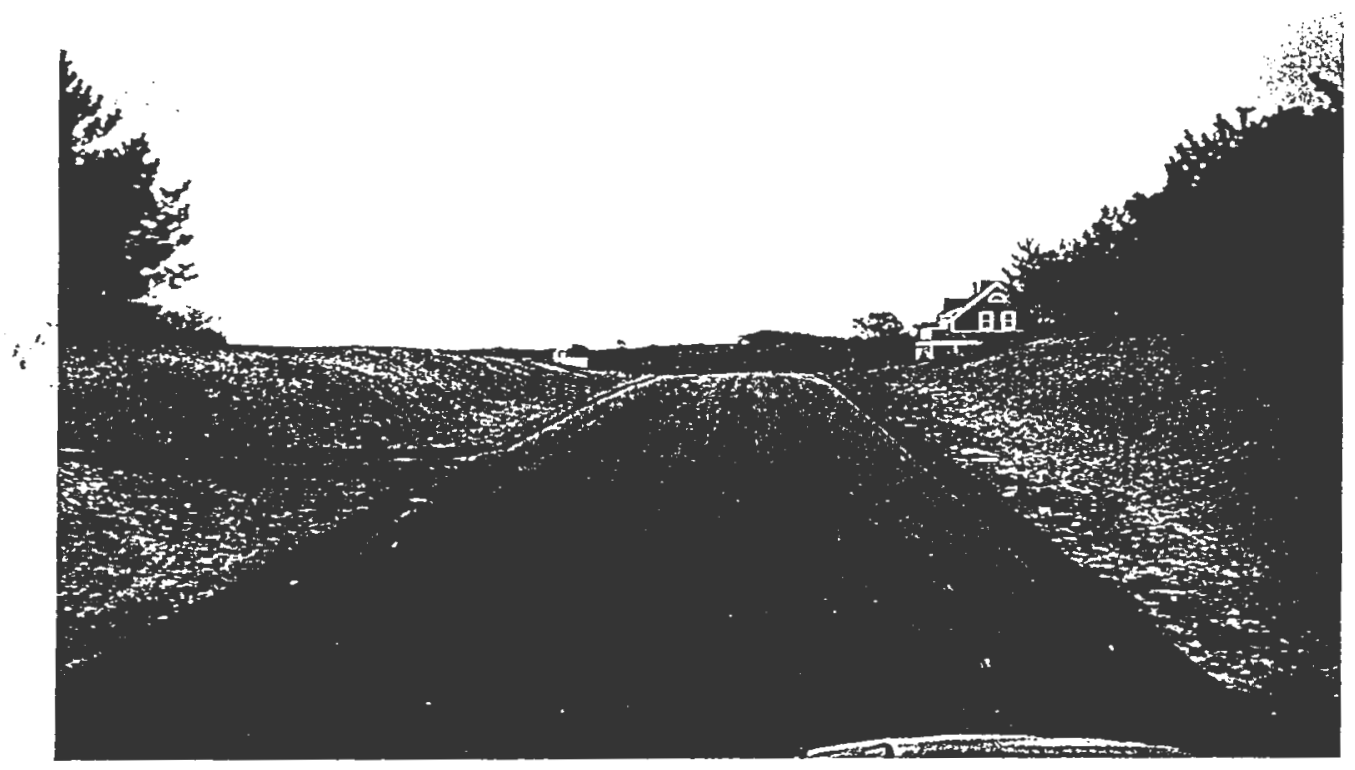

\section{Figure 14: Marion Acres Subdivision}

This subdivision was designed according the Nantucket subdivision regulations which specify 20foot paved roads. For the three lots proposed, the road is wo wide. In addition, given the low number of homes, the road could have casily been constructed of gravel which would have given the road a much softer appearance and been more appropriate.

If a subdivision is too large for gravel roads, one way to soften the look of the ashpalt road is to chip seal the road surface. This is a process where liquid asphalt is sprayed onto the paved surface and then small crushed stone is spread over the liquid asphalt. It gives the street a gravel road appearance even though it is a paved road. 


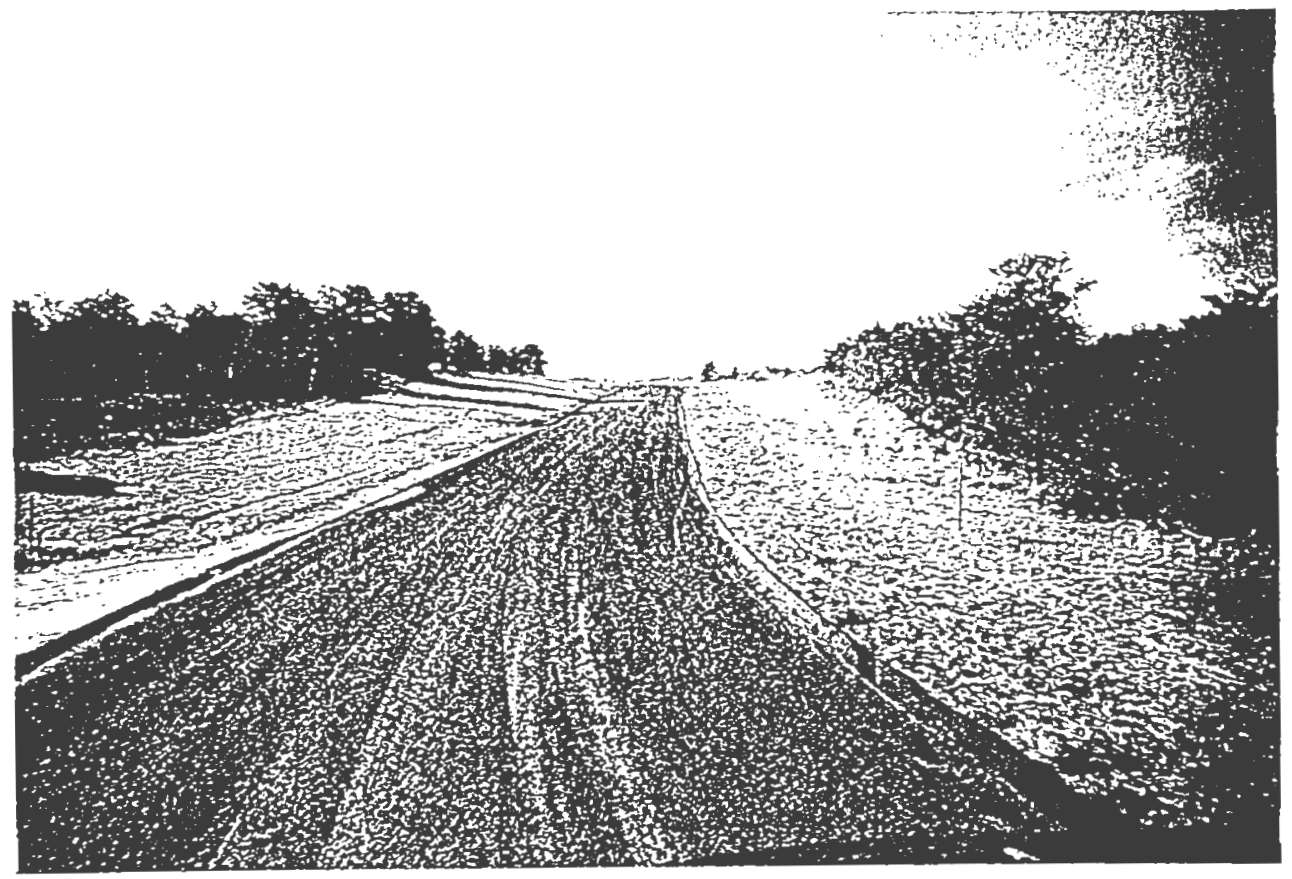

\section{Figure 15: Chip-Sealed Road}

Figure 15 shows the textured surface which closely resembles at gravel road even though it is a paved road. The photo also reveals a very important aspect of subdivision construction. Notice how wide the clearing is on each side of the road. When this road was constructed, a bulldozer came in and cleared a 40 or 50 foot wide swath for the road which is only 20 feet wide. What is left is a gigantic seare on the landscape which will take years to return to a natural look. 
In comparison, the photograph below (Figure 16) shows what a road looks like when the shoulders have not been excessively cleared.

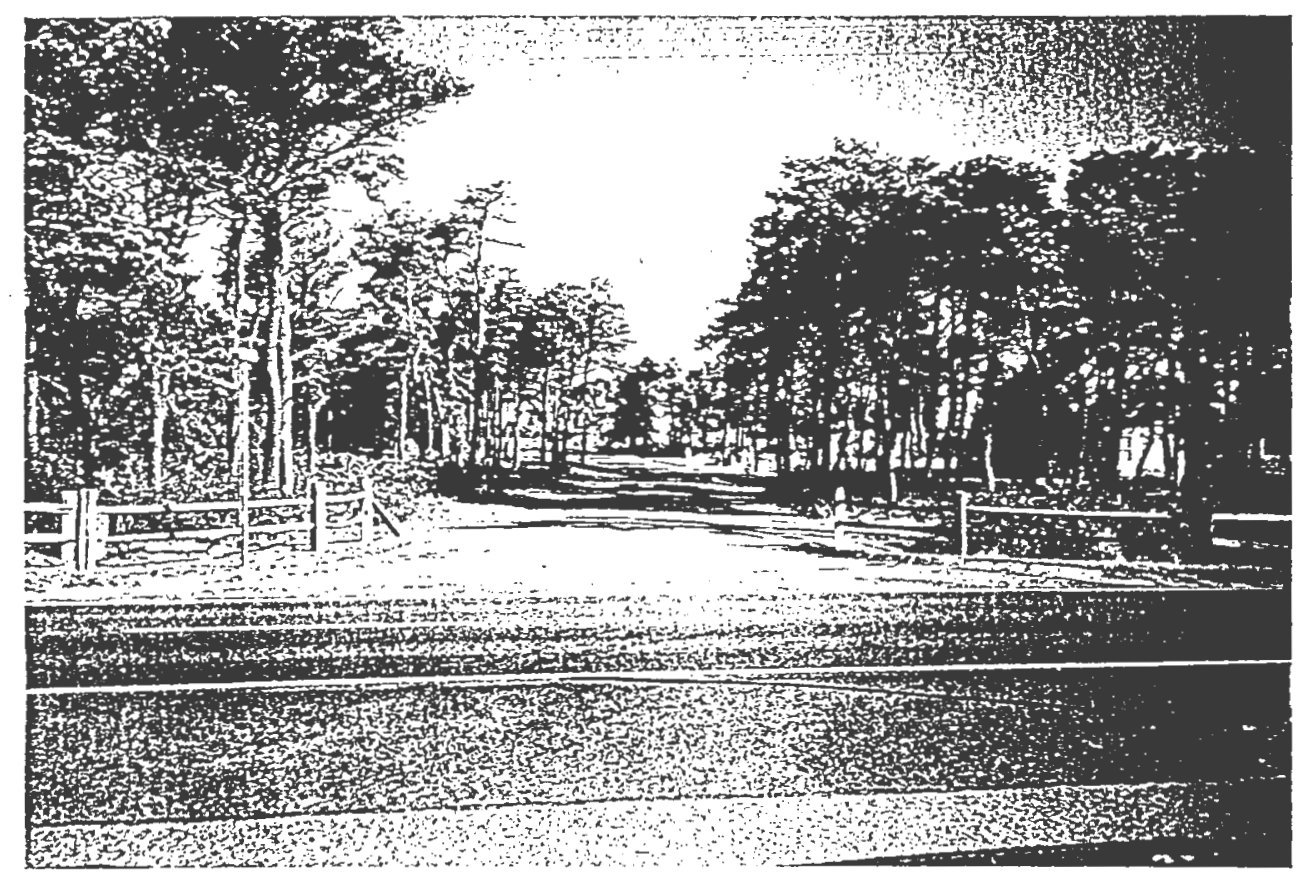

Figure 16: Subdivision Road with Narrow Shoulders 


\section{Chapter 4 \\ Review of Subdivision Regulations of Other Communities}

\subsection{Design Guidelines}

A review of subdivision regulations from many other Massachusetts communities revealed that many were not very innovative in the area of design, and were actually in need of revision. Out of approximately ten communities contacted, only three or four indicated that they had recently done revision work in the area of design. The others indicated that their regulations were very generic with little incentive or guidance on promoting good development.

From the communities that did have progressive regulations, one very useful element found was a "goals for design" section. Nantucket's subdivision regulation lacks this type of statement entirely. The "Rules and Regulations Governing the Subdivision of Land" for both Duxbury (December 1996), and Bellingham (May 1996), Massachusetts, have a Design Guidelines subsection within their Design and Construction Section. They are almost identical and mandate that all roadway and drainage design shall accomplish following goals:

\section{REDUCE, TO THE GREATEST EXTENT POSSIBLE:}

a) Volume of cut and fill;

b) Area over which existing vegetation will be disturbed, especially if within 200 feet of a water body, wetlands resource area, or a slope of more than 15\%;

c) Number of mature trees removed;

d) Extent of waterways altered or relocated;

e) Visual impact of man-made elements not necessary for safety;

f) Erosion or siltation;

g) Alteration of natural valley flood storage areas;

h) Disturbance of important wildlife habitats, outstanding ecological or botanical features, scenic views or historic resources; and

i) Detrimental impacts to nuter quality. 
INCREASE, TO THE EXIENT REASONABLY POSSIBLE:

a) Vehicular use of principal streets to avoid traffic on secondary and minor streets providing house frontages;

b) Visual prominence of natural features of the landscape;

c) Legal and physical protection of views from public ways;

d) Design street layouts to facilitate southern orientation of houses;

e) Use of curvilinear street patterns;

f) Pedestrian and bicycle access and safety; and

g) Natural green belt \& trees, etc. on lots.

These general principals for design are a very good way to set the stage for specific requirements which will promote high quality subdivision. Nantucket's regulation does not have these types of goals identified in its design section. Language similar to this would be an excellent enhancement to the Design Standards section.

\subsection{Street Layout}

Street layout is one of the most significant aspects of subdivision design. Street layout is the path a road takes over the land being developed. In rural developments the layouts should follow the natural topography where possible and avoid areas with significant constraints such as steep slopes, sharp valleys, important vegetation and trees. The curvilinear pattern is well suited to rural developments because it allows the road to wind through an area avoiding obstacles and creating a pleasant driving experience.

As suggested in a report prepared by the Cape Cod Commission (Cape Cod Commission 1995), street curve radius minimums should be reduced in order to allow more flexibility in designing street layouts. The reduction of curve radii would permit sharper corners, more winding 
patterns where appropriate (rural curvelinear designs), and streets which are more sensitive to the existing landscape. In addition, streets with sharper corners would serve to slow traffic speeds down, although caution must be taken so as not to create a long straight-away leading up to a sharp curve for safety reasons.

In Nantucket, another street pattern which will be used is the rectilinear pattern of straight streets meeting other streets at right angles. This is the most traditional style of street layout and is typical of the historic downtown in Nantucket. One distinction in Nantucket is that the rectilinear pattern is not completely orderly. It tends to have variations such as roads that make angled connections from one block to another.

\subsection{Street Width}

In a report prepared by the Cape Cod Commission, "Old King's Highway/Route 6A Corridor Management Plan", a review of seven town subdivision regulations revealed that subdivision roadway width requirements vary from as little as 14 feet to as great as 30 feet. Some towns require the preparation of an environmental impact report which would examine the potential traflic impacts of the project. In addition, Cape Cod Commission research suggests the requirement of a traffic impact analysis for any project exceeding 25 vehicle trips per hour or a given size threshold. (Rt. 6A Plan, p.75) Although having the ability to require a traffic impact assessment is a valuable element, the lack of potential for large scale developments in Nantucket makes this ability less important.

More signilicant, the report recommends that subdivision roadway widths be scaled to reflect the intensity of use, suggesting that for low density residential streets, pavenent widths be 
20 - 22 feet depending on the projected traffic volume. In Nantucket, 20 feet is the maximum width the Planning Board would require for any subdivision. A. 2()-foot wide paved roadway width would be typically required for subdivisions of ten lots or more. Under ten lots, the required width could be 16 or 18 feet. The Board has approved widths of less than 16 feet in rural areas, but often problems result such as the inability for two normal sized vehicles to pass, or large commercial trucks such as construction equipment must use the shoulder which is often not strong enough, resulting in deep rutting of grassed areas. This points to the need for more careful design when considering narrow roadway widths of less than 16 feet.

The Cape Cod Commission recommendations also suggest minimizing clearing and grading for subdivision roadways and reducing radius requirements and replanting of cleared areas with new street trees. (Rt. 6A, p. 80) Additionally, the report suggests avoiding the use of curbing where possible, or the consideration of using Cape Cod berms. This is an interesting suggestion, as the Planning Board has required granite curbing at corners and intersections of rural subdivisions which looks completely out of place. Granite curbing is more appropriate in developments in or near to town with rectilinear street patterns of tradition design. The historic downtown has granite curbing through-out. 
The following is data collected from various Massachusetts community subdivision regulations. As you can see, the average road width requirement is about 20 feet. Duxbury actually allows widths of 18 and 14 fect.

TABLE 4: Street Width

\begin{tabular}{|c|c|c|c|}
\hline Town & \# of Lots Served & Minimum Pavement Width & Required Curbing \\
\hline \hline Duxbury & $1-3$ & $14 \mathrm{ft}$. & $1.5 \mathrm{ft}$. \\
\hline & $4-10$ & $18 \mathrm{ft}$. & $1.5 \mathrm{ft}$. \\
\hline over 10 & $22 \mathrm{ft}$. & $1.5 \mathrm{ft}$. \\
\hline Bellingham & 12 or less & $22 \mathrm{ft.}$ & 0 \\
\hline & $13-49$ & $26 \mathrm{ft}$. & 0 \\
\hline Harer 50 & $30 \mathrm{ft}$. & 0 \\
\hline minor & $20 \mathrm{ft}$. & $1.5 \mathrm{ft}$. \\
\hline
\end{tabular}




\section{Chapter Five}

\section{Literature Review}

\subsection{Homeowner Preferences}

In order to identify new and innovative ideas for subdivision design an extensive literature search was conducted. Surprisingly, there is relatively little good information on street design and layout specifically. Much of the literature focuses on the siting of houses in relation to the streets, lot layout for large scale subdivision, and street layout for large scale subdivision. There was not a lot of information which could be directly applied to Nantucket's situation. What information was pertinent is review below.

A survey of perspective home buyers in a recent article from Urban Land Magazine identified "low traffic area" as the number one desired feature with a 93\% positive response. $77 \%$ of the respondents desired cul-de-sac streets, circles, and courts.

Table 5: Summary of Subdivision Features (percentage saying feature is very or extremely important)

\begin{tabular}{|l|c|}
\hline Low Traffic Area & $93 \%$ \\
\hline Cul-De-Sac Streets, Circle, \& Courts & $77 \%$ \\
\hline Natural Open Space Areas & $77 \%$ \\
\hline Walking \& Bike Paths & $74 \%$ \\
\hline Established Schools & $69 \%$ \\
\hline Architectural Style \& Lot Size Controls & $69 \%$ \\
\hline Sidewalks Along One Side of all Streets & $66 \%$ \\
\hline
\end{tabular}

Source: American LIVES, Inc. and InterCommunications Inc.

The top two items on the list are directly related. Cul de sac street, circles, and courts are by 
nature low traflic areas. Real estate agents in Nantucket confirm this desire for low traffic neighborhoods, stating that house lots at the end of dead-end streets are very popular. This setting tends to be more quite and safer for children to play in. Although these types of streets are strongly desired throughout the U.S., a proliferation of dead-ends will eventually lead to traffic congestion. By allowing mostly dead-end streets, all of the traffic gets funneled onto relatively few collector streets. These collector streets can become overburdened and drivers have no other alternatives because there are no other connector streets to distribute traftic. Therefore, before permitting dead-end streets, overall traffic circulation patterns and long range planning should be carefully considered.

The article predicts that due to the growing desire for neotraditional type development, infill development will become increasingly attractive to developers. This is especially true for Nantucket where there is very little open land left to be developed.

\subsection{New Urbanism/Neotraditional Planning}

Although the ideas of New Urbanism and Neotraditional Planning have identified ways of designing better developments than the typical sprawl style subdivision, it cannot be easily applied to Nantucket. Most of the concepts of New Urbanism and Neotraditional Planning relate to master planning an entire village. As previously discussed, Nantucket no longer has the raw land available for such large scale developments. In addition, to actually do this type of planning would require zoning changes which permit commercial uses in residential districts along with changes to yard setbacks and minimum lot sizes. In Massachusetts changing the underlying zoning requires a two thirds rote of all citizens voting at a local town meeting, 
whereas the changing the subdivision regulations only requires a public hearing by the Planning Board and a major vote of the Planning Board. Therefore, this project will not suggest zoning changes.

Fortunately, New Urbanism and neotraditional planning have many positive aspects which can be applied to small infill subdivision development to compliment existing neighborhoods. A report prepared by the "World Idea Networks" (World, p. 3) identifies many of the important elements of New Urbanism or neotraditional design:

1. Relatively narrow streets shaded by rows of trees - this slows down the traffic, creating an environment for the pedestrian and the bicycle;

2. Connecting strects - dead-end/cul de sac roads are not traditional;

3. Create alleys for access to garages and parking - easier to accomplish when designing a larger subdivision or approximately 20 lots or more; and

4. Small playgrounds - also more appropriate for larger subdivisions.

The first two design elements deseribed above are the ones most applicable to Nantucket due to the small scale nature of Nantucket's future subdivisions.

Traffic calming is a relatively new term used to describe a "form of traffic planning that seeks equalize the use of streets between automobiles, pedestrians, bicyclists, and playing children." (Hoyle p. 1) In Hoyle's book, Traffic Calming, she describes how streets have a major inlluence on the quality of life within the area served by the street. The major goals of traffic calming are to:

1. Slow down the speed at which automobiles travel;

2. Change the psychological feel of the street;

3. Increase the incentives to use public transportation;

4. Discourage the use of private motor vehicles;

5. Encourage people to organize their own travel more efliciently; and 
6. Create strong viable local communities.

Hoyle $(1995,16)$, in describing techniques to enhance the feel of a street, points out the importance of selecting the proper street trees that, when mature, do not obscure the sight lines For either drivers or pedestrian. These trees are an important component of creating a sense of place. The use of traflic calming techniques can serve to create safer and more pedestrian and bicycle friendly streets, and at the same time create streets which have community character.

One concept, first used in Holland, is to create pedestrian or residential streets. This is done by eliminating sidewalks and curbing with the entire surface being paved for pedestrians. The actual street width is approximately six feet with widened turn-outs every 100 leet. This technique or a variation of it would be well suited to much of the future in-fill development on Nantucket. It seems especially appropriate for shorter street lengths of approximately 100 to 200 feet.

The ideas of New Urbanism and Neotraditional planning seem to really apply well to Nantucket's "in-town" developments. In fact, Nantucket gets mentioned often when writers are describing existing communities that embody the concepts of this type of planning. Nantucket's downtown has all of the required components with the exception of the village green. Therefore, the concepts of New Urbanism and Neotraditional planning should be incorporated into subdivisions proposed near the urbanized downtown area and will be expanded on in the following recommendations. 


\section{Chapter 6}

\section{Recommendations for Revising Nantucket's Subdivision Regulations}

\subsection{Purpose Statement}

The very first thing a developer should see when they start to read Nantucket's Subdivision Regulations is a statement of the purpose of the regulations. The existing purpose section speaks of many aspects such as safety and convenience but does not speak about how a new development should respect the traditional charaeter of the surrounding area and strive 10 blend in with the predominant characteristics of that area. This is appropriate for both "intown" development where the historic homes are the focus, and for "out-of-town" (rural) development where the natural landscape is the dominant characteristic. The specific design elements for each type of development will be elaborated on in the Sections 6.2 and 6.3 .

\subsection{Design Guidelines}

Section Ill, Subdivision Layout Design Standards, of the existing regulations should start with a subsection entitled "General Design Guidelines" which would read as follows: REDUCE, TO THE GREATEST EXTENT POSSIBLE:

a) Volume of cut and fill;

b) Area over which existing vegetation will be disturbed, especially if within 200 feet of a water body, wetlands resource area, or a slope of more than 15\%;

c) Number of mature trees removed;

d) Extent of waterways altered or relocated;

c) Visual impact of man-made elements not necessary for safety;

f) Erosion or siltation;

g) Alteration of natural valley flood storage areas; 
h) Disturbance of important wildlife habitats, outstanding ecological or botanical features, scenic views or historic resources; and

i) Detrimental impacts to water quality.

INCREASE, TO THE LXTENT REASONABI,Y POSSIBLE:

a) Vehicular use of principal strects to avoid traffic on secondary and minor streets providing house frontages;

b) Visual prominence of natural features of the landscape;

c) Legal and physical protection of views from public ways;

d) Design street layouts to facilitate southern orientation of houses;

e) Use of rectilinear street patterns for in-town development;

f) Use of curvilinear street patterns for out-of-town development;

g) Pedestrian and bicycle access and safety; and

h) Natural green belt \& trees, etc. on lots.

This language was borrowed from the Duxbury and Bellingham subdivision regulations

reviewed earlier and modified to better fit Nantucket's needs. It sets the framework for how a proposed subdivision will be reviewed and explicitly states the Town's priorities.

\subsection{In-Town and Out-of-Town Development Categories}

The previous recommendation raises the need for two individual categories of development. As discussed earlier, in Nantucket there will be primarily two types of subdivisions; the "in-town" style, and; the "out-of-town" or rural style of development. They each have very different characteristics and therefore must be separately defined. The Planning Board should adopt a map defining the two separate zones, which a developer would use to identify what district their proposed subdivision is in.

It is very important for the street infrastructure of "in-town" subdivisions to compliment the character of the existing streets immediately surrounding the development. If 
the abutting street has brick pavers for a surface, then a developer should be required to match the type of pavers used previously. For a Planning Board to required this it must be spelled out explicit in the regulations. Similarly, if the abutting streets have brick sidewalks then the new road should have brick sidewalks also. The other details such as street tree locations and types, curbing material and style, and street lighting should compliment the existing infrastructure.

Therefore, the proposed section regarding "in-town" developments should contain a statement which lets developer know that they will be required to encorporate design elements such as those mentioned above to match the styles of the immediately surrounding area.

The "In-Town" or "Downtown" style developments would be required to have the following elements as part of their proposal:

1. Rectilinear strect patterns where feasible;

2. Cobblestone, brick, belgian block, or pavers used for the road surfaces;

3. Brick sidewalks;

4. Traditional gas lantern style street lights;

5. Granite curbing;

6. Many large street trees; and

7. No eul de sac turnarounds shall be permitted.

There are several other features important to good "in-town" development such as houses all set along the street line to form a continous facade, picket fences, and architectural review, but these elements do not belong in the subdivision regulations due to their state defined limitations.

The beginning of the proposed section on "out-of-town" subdivisions should identify the goal of minimizing the impacts of a new development on the surrounding natural environment. In addition. to minimizing impacts, a developer should strive to soften the 
appearance of the roads.

\subsection{Out -of-Town Development Category}

The "Out-of-Town" or "Rural" style developments should be required to have the following elements:

1. Curvelinear street patterns where feasible;

2. Straight runs of roadway should be avoided;

3. Circular cul de sac turnarounds should be avoided;

4. Where appropriate gravel roads should be considered;

5. If the size of a development required asphalt pavement, the surface should be chip sealed to resemble a gravel road;

6. Clearing of natural vegatation for roadway should be minimized and limits of clearing clearly posted in the field prior to any construction; and

7. An effort should be made to save all significant trees, which should be marked clearly in the field.

Establishing these two separate categories of development and identifying their key

design elements will be perhaps the most significant addition to the existing regulations because it will clearly identify the style of development the Planning Board is looking for from any newly proposed project. In addition, if these design elements are missing from a developer's proposal, the Planning Board can point to their regulations and require the developer to encorporate those components.

\subsection{Roadway Layout}

We have already discussed the need to have "in-town" roads laid out in a rectilinear pattern, and "out-of-town" roads laid out in a curvelinear pattern. For both styles of development cul de sac turnarounds should be discouraged. Although they are somewhat of a 
standard for dead-end streets, they are very untraditional. They are a standard because they accomplish the task of turning cars and other vehicles around with the most convenience, and therefore are very common.

There are several alternative designs which could replace a cul de sae such as those shown below.
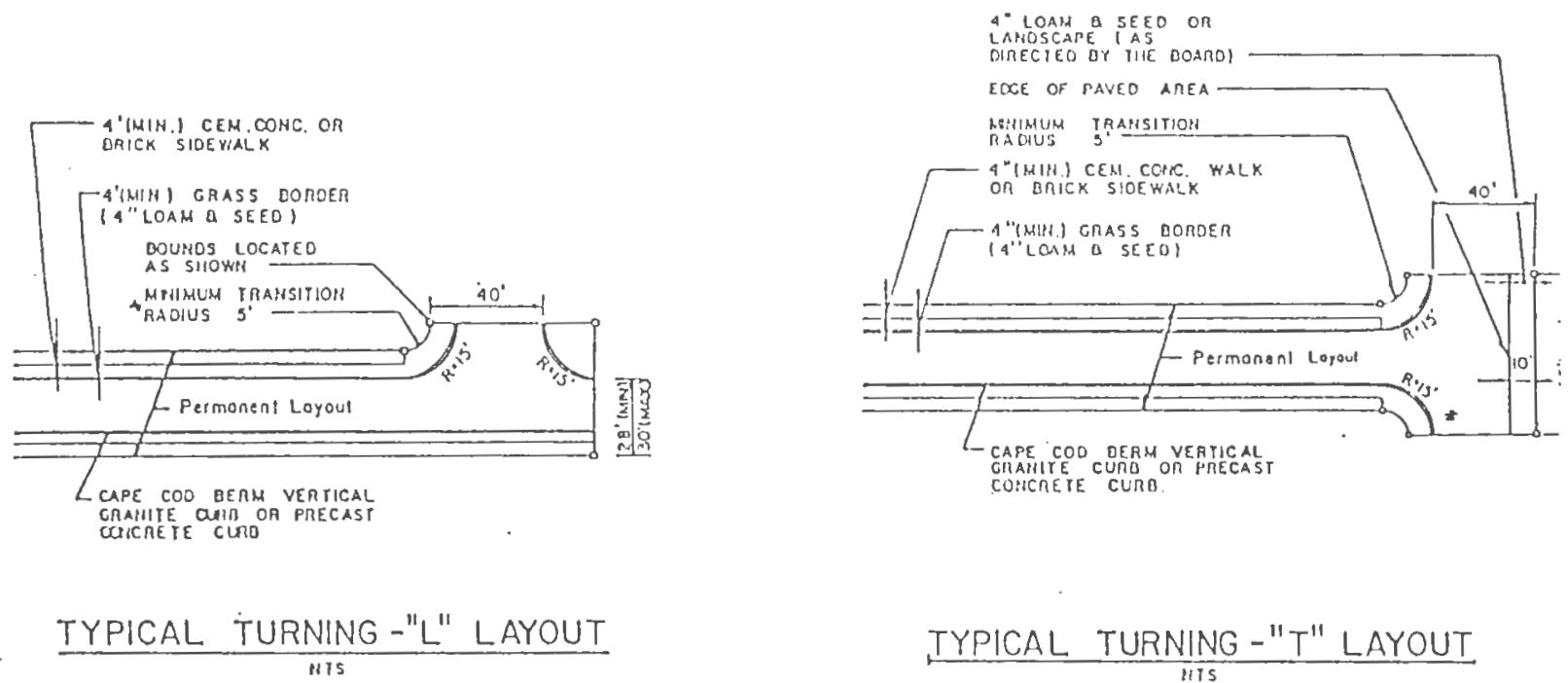

Figure 17: Turning " $L "$ and Turning "T" Layouts Source: Nantucket Subdivision Regulations

These types of turn-arounds are in Nantucket's regulation but are alternatives. They should be moved into the layout section where dead-end streets are discussed and cul de sacs should only be used when the number of house lots on a dead-end exceeds around 10 homes. When a cul de sac is required due to the size of a subdivision, it should not be configured as a circular turnaround. These look very unnatural and should be replaced with a turnaround with a varied path which will somewhat more natural and less formal. 


\subsection{Roadway Widths}

Although Nantucket's required road widths are not too exeessive, there is room for improvement. For both "in-town" and "out-of-town" developments, developers should be encouraged to minimize the necessary roadway widths. For "in-town" developement this is especially important due to the historically narrow street built before the existence of cars. In "out-of-town" developments it is equally important because a narrower road will more easily blend in the the natural environment and cause less disruption of the natural vegatation.

The width required for any given subdivision road is a function of the proposed number of house lots, the length of the roads proposed, and the layout of the road. In the future, "intown" projects will tend to very short roads due to the lack of larger undeveloped lots. This will make it easier to design appropriate narrow roads with widths of 12 to 16 feet.

For "out-of-town" projects, the road widths will have to be more carefully considered. Any width less than 16 feet will not leave room for two cars to pass each other on the road, and therefore will require the inclusion of turn-outs at appropriately spaced intervals to facilitate two-way traffic. Narrow rural roads about 12-foot wide with turn-outs can be very effective in minimizing the visual impact of a road, and at the same time keep vehicle speeds low.

\subsection{Conclusions}

The review of Nantucket's subdivision regulations reveals that they do very little to promote good new development which would compliment existing development. Most of the 
body of the existing regulations are involved with promote safety and convenience for vehicular traffic. While safety is extremely important and can never be overlooked, there are ways to make a subdivision look like it fits in with surrounding development and still keep it safe.

Whether a development is proposed in the already urbanized downtown vicinity, or is proposed for a rural area far from the downtown, a developer should be guided by the regulations to design their project to fit in. This is especially important for a place such as Nantucket because of its long history and all of the other efforts to preserve its historic heritage. This is exemplified by the fact that the entire island is designated as a historic district and every structure proposed to be built must be approved by the Historic District Commission.

All the efforts to promote historic architecture on the island are lost when a historically designed home is built in a subdivision that looks out of place. Therefore, the Planning Board responsible for reviewing and approving subdivisions, must have a set of regulations that enforce the goal of preserving community character. To this day, Nantucket still does not have a single traffic light.

Hopefully the recommendations suggested in this paper could be considered by the Planning Board and the public, and the concepts incorporated into the existing regulations. None of the suggestions would be overly onerous and in some instances they would be less demanding on a developer. 


\section{Bibliography}

Bobrowski, Mark. "Handbook of Massachusetts Land Use and Planning Law." Boston, MA: Little, Brown and Company, 1993.

Cape Cod Commission. "A Design Guideline Manual for Sustainable Development on Cape Cod." 1992.

Cape Cod Commission. "Designing the Future to Honor the Past." ......

Cape Cod Commission. "Old King's Highway/Route 6A Corridor Management Plan." April 1995.

Department of Housing \& Community Development, MA. "Subdivision Control Law: An Overview of the Subdivision Control Law." 1996.

Doble, Cheryl S. and George M. McCulloch. "Community Design Guidelines Manual." New York State Tug Hill Commission, 1991.

Herr, Philip B. and Associates. "Good Rural Subdivision." 1990.

Heyer, Fred. "Preserving Rural Character." Planning Advisory Service Report \#429. American Planning Association. 1990.

Hoyle, Cynthia L. "Traffic Calming." Planning Advisory Service Report \#456, 1995. American Planning Association. 1995.

Jarvis, Frederick D. "Site Planning and Community Design for Great Neighborhoods." Washington, D.C.: Home Builder Press, 1993.

Lang, Christopher J. and Kate Stout. "Building with Nantucket in Mind." Orleans, MA: Paraclete Press, 1992.

Listokin, David and Carolé Walker. "The Subdivision and Site Plan Handbook. "New Brunswick, NJ: Center for Urban Policy Research, 1989.

Nantucket Planning \& Economic Development Commission. "Goals and Objectives for Balanced Growth." 1990.

Nantucket Planning Board. "Rules and Regulations Governing the Subdivision of Land." Amended through January 1991. 
Pioneer Valley Planning Commission, MA. "Artificial Recharge: Evaluation and Guidance to Municipalities." November 1996.

Sanders, Welford. "The Cluster Subdivision: A Cost-Effective Approach." Planning Advisory Service Report \#356, 1980.

Trancik, Roger. "Hamlets of the Adirondacks: Development Strategies." Ithaca, NY. 1985.

Urband Land Institute, National Association of Home Builders, American Society of Civil Engineers. "Residential Streets, 2nd Ed." 1990.

Warrick, Brooke and Toni Alexander. "Looking for Hometown America." Urban Land. February 1997. pp.27-29, 51-53.

World Idea Networks. "Case Study Library: Neotraditional Development Kit. Vol. 1." 1997.

Yaro, Robert D. and Randall G. Arendt. "Dealing With Change in the Connecticut River Valley: A Design Manual for Conservation and Development, 2nd printing. " Lincoln Institute of Land Use Policy and the Environmental Law Foundation, 1988. 